

\title{
NEW PUBLICATIONS FROM THE
}

Harvard

University Asia Center

\section{CHINESE HISTORY \\ A Manual \\ ENDYMIONWILKINSON}

A comprehensive, up-to-date guide to problems encountered in researching traditional Chinese civilization and history, with discussions of 2,500 primary sources and reference works and 500 outstanding contributions of modem scholarship. $\$ 19.95$ paper (also available in cloth) $\cdot 1,080 \mathrm{pp}$.

\section{HIRAIZUMI}

Buddhist Art and Regional Politics

in Twelfth-Century Japan

MIMIYIENGPRUKSAWAN

An analysis of the use of the power of art and architecture by the rulers of Hiraizumi in northem Japan to claim a religious and political mandate to rule. $\$ 60.00$ cloth $\cdot 103$ illustrations ( 11 in color) $\cdot 3$ maps $\cdot 300 \mathrm{pp}$.

\section{OTHER RECENT PUBLICATIONS}

\section{POWERFUL \\ RELATIONS}

Kinship, Status, and the State in Sung China (960-1279) BEVERLEY J. BOSSLER $\$ 45,00$ cloth $\cdot 370 \mathrm{pp}$.

\section{STUDIES IN THE COMIC SPIRIT IN MODERN JAPANESE FICTION \\ JOEL R. COHN} $\$ 40.00$ doth $\cdot 254$ po.

\section{LMMTED VIEWS}

Essays on Ideas and Letters QIAN ZHONGSHU TRANSLATED BY RONALD EGAN $\$ 45.00$ doth $-484 \mathrm{pp}$
THE SIMILITUDE OF BLOSSOMS

A Critical Biography of Izumi Kyōka (18731939), Japanese Novelist and Playwright

\section{CHARLES SHIRŌ INOUYE}

A critical biography arguing that lzumi's visual mode of figuration is his compromise between literary modernism and Japanese fiction of the Edo period. $\$ 40.00$ doth -22 illustrations $-402 \mathrm{pp}$

\section{CRAZY J}

Chinese Religion and Popular Literature

$$
\text { MEIR SHAHAR }
$$

A study of the role of popular literature in shaping religious beliefs, focusing on Crazy fi, one

of the most colorful gods in the pantheon

of late imperial and modem China.

$\$ 19.95$ paper (also avalable in doth) • 20 ilustrations, 2 maps • 352 pp

\section{STUDIES IN CHINESE POETRY}

JAMES R. HIGHTOWER AND FLORENCE CHIA-YING YEH

A collection of three essays on shih poetry, ten studies of Sung tz'u, and four chapters on the poetry of Wang Kuo-wei, treating individual poets,

poetic techniques, and poetry criticism. $\$ 50.00$ doth - $632 \mathrm{pp}$.

DISTRIBUTED BY HARVARD UNIVERSITY PRESS

US: 8004482242 UK: 0713060603 www.hup.harvard.edu 


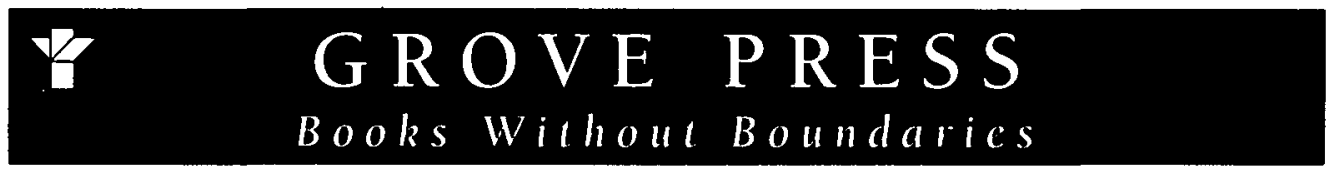

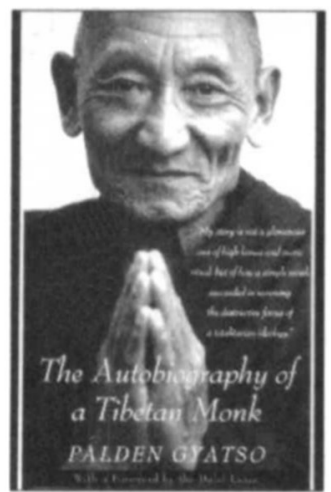

THE AUTOBIOGRAPHY

\section{OF A TIBETAN MONK}

\section{Palden Gyatso}

With an Introduction by the Dalai Lama

"Tibet's suffering exerts a profound claim on the world's compassion.... In writing this wrenching memoir of extraordinary suffering, resistance, and endurance, Palden Gyatso has testified not only to the pain of countless individuals but to the devastation of a nation."-The New York Times Book Review

0-8021-3574-9 • \$13 $\cdot 256 \mathrm{pp}$.

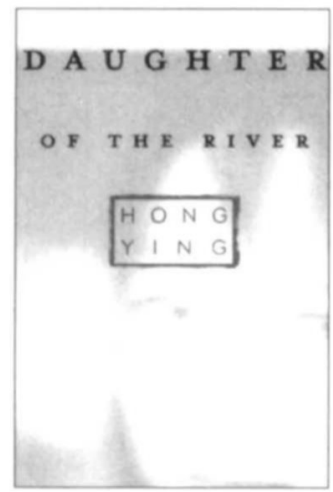

\section{DAUGHTER OF THE RIVER}

\section{AN AUTOBIOGRAPHY}

\section{Hong Ying}

With searing lyricism, Daughter of the River portrays the coming-of-age of a young writer in the urban slums of Communist China.

"Hong Ying's prose ... is both sensuous and lapidary, eloquently expressing $|\mathrm{a}|$ wide emotional and intellectual range."-The New York Times Book Review $0-8021-1637-X \cdot \$ 24 \cdot 288 \mathrm{pp}$. • January 1999

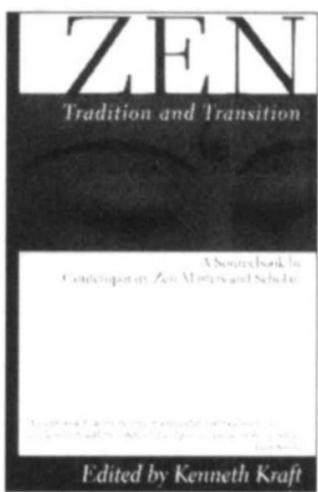

TENTH-ANNIVERSARY EOITION

ZEN: TRADITION AND TRANSITION A SOURCEBOOK BY CONTEMPORARY ZEN MASTERS AND SCHOLARS

\section{edited by Kenneth Kraft}

Contributors include: Martin Collcutt $\bullet$ T. Griffith Foulk • Philip Kapleau • Albert Low • John R.

McRae - Morinaga Soko $\bullet$ Eido T. Shimano $\bullet$ Burton Watson - Philip Yampolsky • Sheng-Yen

"Refreshing and salutary ... This book strongly presents the dynamic interface of continuity and change in Zen in North America,"-Joumal of Asian Studies $0-8021-3162-X \cdot \$ 12 \cdot 240 \mathrm{pp}$.

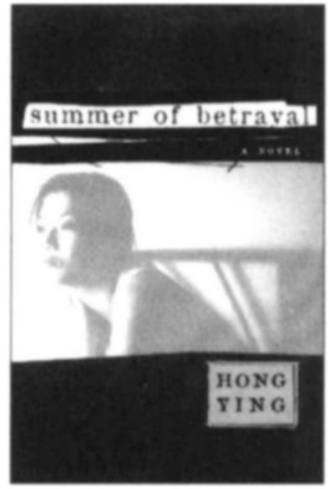

\section{SUMMER OF BETRAYAL}

\section{A NOVEL}

\section{Hong Ying}

Originally published in Taiwan in 1992 and now banned in China, Summer of Betrayal is an astonishing and powerful first novel that establishes Hong Ying as one of China's most outspoken and talented voices.

"A bold and compelling novel that flaunts China's prohibitions against public discussion of the Tiananmen events ... a searing portrait of political defiance and sexual rebellion ... powerful."-Los Angeles Times Books Revien

$0-8021-3594-3 \cdot \$ 12 \cdot 192$ pp. • January 1999

To place an order please contact Grove Press, distributed by Publishers Group West. Publishers Group West, 1700 Fourth Street, Berkeley, CA 94710 tel.: 800-788-3123 fax: 510-528-5111 


\section{NEW FROM PENGUIN PUTNAM INC.}

\section{THE RAPE OF NANKING}

THE FORGOTTEN HOLOCAUST

OF WORLD WAR HI

\section{IRIS CHANG}

The first comphrehensive examination of the destruction of this Chinese imperial city..Ms. Chang, whose granparents narrowly escaped the carnage, has skillfully excavated from obliv: ion the terrible events that rook place:"-The Wall Strcet loumal "Anyone interested in the relation between war, selfrighteousness, and the human spirit will find The Rape of Nanking of fundamental importance. It is a scholarly and exciting investigation, and a work of passion."-Ross Terrill, author of Mao, China in Our Jime, and Madame Mao.

Penguin $\quad 336 \mathrm{pp}$. $0-14-027744-7$ ( $\$ 14.95$

\section{A NEW HANDBOOK OF LIVING RELIGIONS} Second Edition

EDYTED BY HOHN R. HINNELLS

This completely revised edition contains seven new chaplers, and provides up-to-date information on the sources of the world's religions, from Buddhism to Zoroastrianism. Their teaching, practices, and popular traditions are explored, with charts and diagrams to llitustrate and clarify the text. Developments in recent scholarship include everything from new material on China to information on gender and spirituality, $2 s$ well as the black African diaspora.

Penguin Reference 912 pp.

$$
0-14.051407 .4
$$

$\$ 19.95$

\section{THE COURAGE}

\section{TOSTAND ALONE}

\section{LETTERS FROM PRISON AND OTHER WRITINC:} (Updated for this papertack edition)

Wei lingsheng. Translated by Kris Torgeson.

"An unforgetuable portrait of a man of sublime courage." - Kirkus Reviews. "Despite the impossible circumstances under which they were written, they are an extraordinary and moving record of a courageuus, compassionate, and obstinate mind" - The New York Times Book Review. Wei Jingsheng is the winner of the 1997 Sakharov Peace prize for Frecalom of Thought.
Penguin
0-14-027535-5
$\$ 13,95$
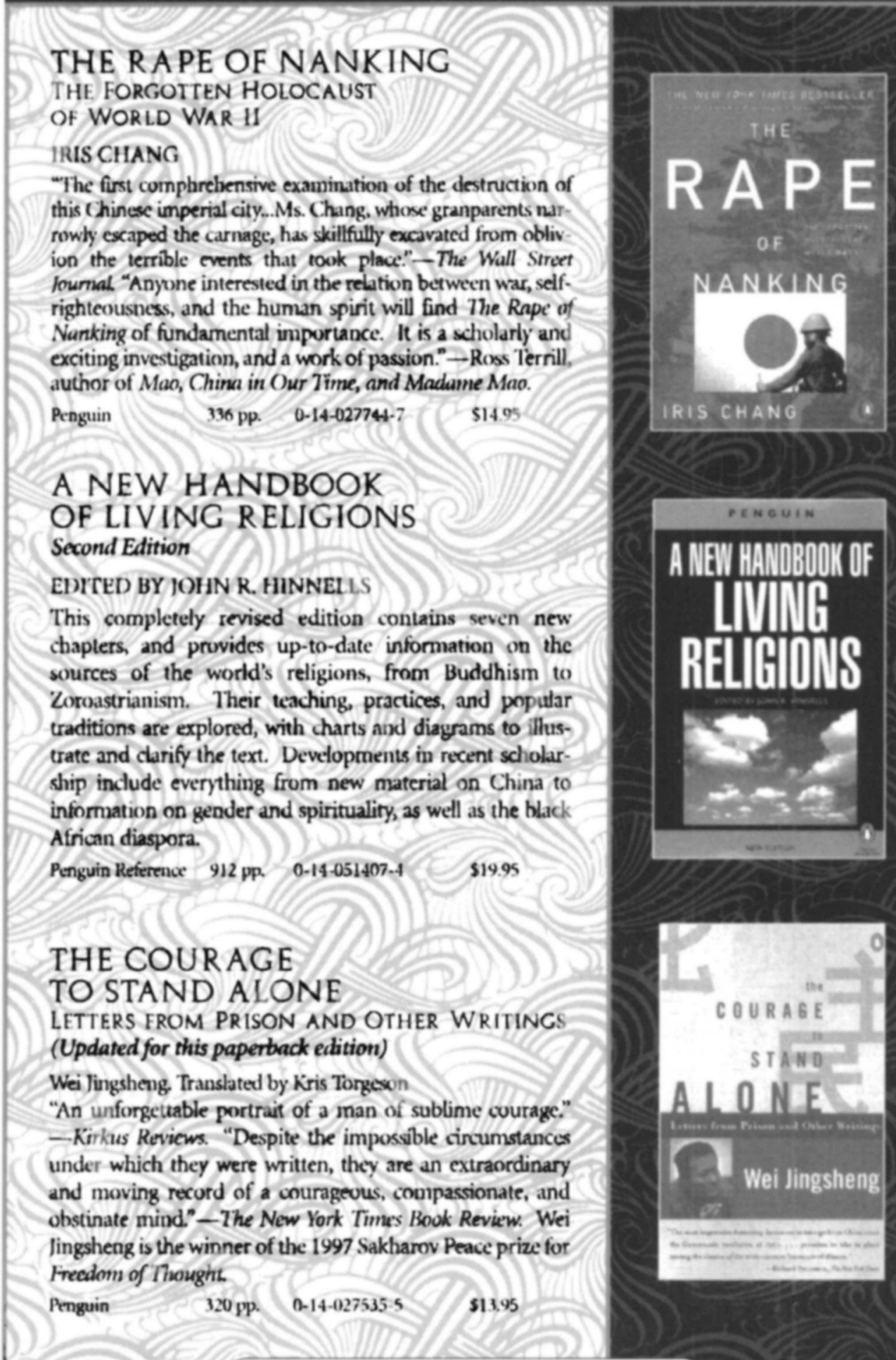


\section{Tiger on the Brink}

Jiang Zemin and China's New Elite

Bruce Gilley

"The first convincing and well-documented account of exactly how Jiang Zemin rose to be China's leader. . . . Thanks to Gilley we can see Jiang as an often canny political operator, who made the most of the opportunities that came his way."

-Jonathan D. Spence, $\$ 29.95$ cloth, illustrated author of God's Chinese Son

\section{A Flourishing Yin}

Gender in Cbina's Medical History, 960-1665 Charlotte Furth

"Highly original, and sophisticatedly and convincingly argued. This book is one of the best studies in any language of how Chinese medicine evolved intellectually and socially in the course of the imperial period."

-Francesca Bray, author of Tecbnology and Gender A Pbilip E. Lilienthal Book, $\$ 45.00$ cloth, $\$ 17.95$ paper, illustrated

\section{China's Catholics}

Tragedy and Hope in an Emerging Civil Society Richard Madsen

"Rich with personal observation and scrupulously researched, this masterful account of repression and survival offers compelling insights into the social, moral and spiritual tensions that underlie China's material prosperity in the 1990s."

-Carolyn Wakeman, $\$ 27.50$ cloth, illustrated

\section{UNIVERSITY OF CALIFORNIA PRESS}

www.ucpress.edu

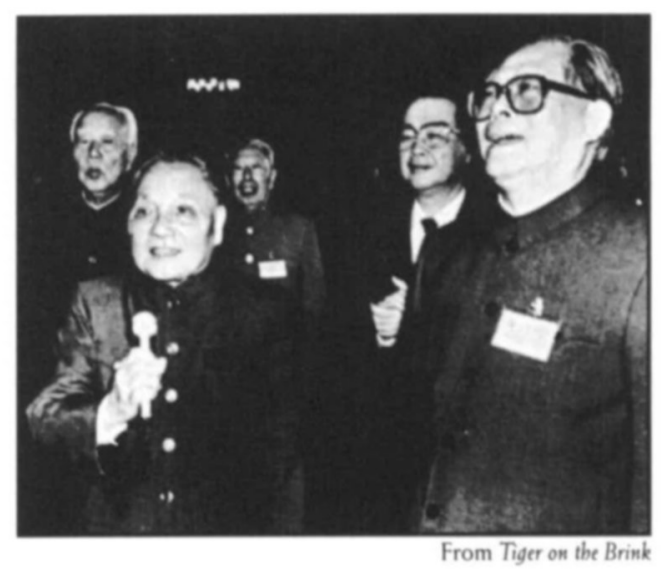

\section{The Last Emperors}

A Social History of Qing Imperial Institutions Evelyn S. Rawski

"This book is of immense importance to the China field. Evelyn Rawski makes the greatest contribution we can expect from a superior scholarly work." - Susan Mann, author of Precious Records

A Pbilip E. Lilientbal Book, $\$ 45.00$ cloth, illustrated

\section{NEW IN PAPERBACK}

\section{Spider Eaters}

\section{A Mernoir \\ Rae Yang}

"Raw and eye-opening .... Yang is an impressive writer whose stirring memoir makes an important contribution to the growing mountain of literature on Mao's revolution and legacy."

-San Francisco Cbronicle Book Review $\$ 16.95$ paper, illustrated

\section{The Attic}

\section{Memoir of a Chinese Landlord's Son \\ Guanlong Cao \\ Translated by Guanlong Cao \& Nancy Moskin "Has affinities with the great literature of suffering from our century. ... Cao [is] a powerful chronicler of his experiences. ... Engrossing." -New York Times Book Review \\ $\$ 15.95$ paper}


The Faces of Buddhism in America

Charles S. Prebish and Kenneth K. Tanaka,

Editors

"This book is sure to be an invaluable resource not only to Buddhist scholars, but to the practitioners as well." -John Daido Loori, Roshi Abbot of Zen Mountain Monastery $\$ 50.00$ cloth, $\$ 22.00$ paper, illustrated

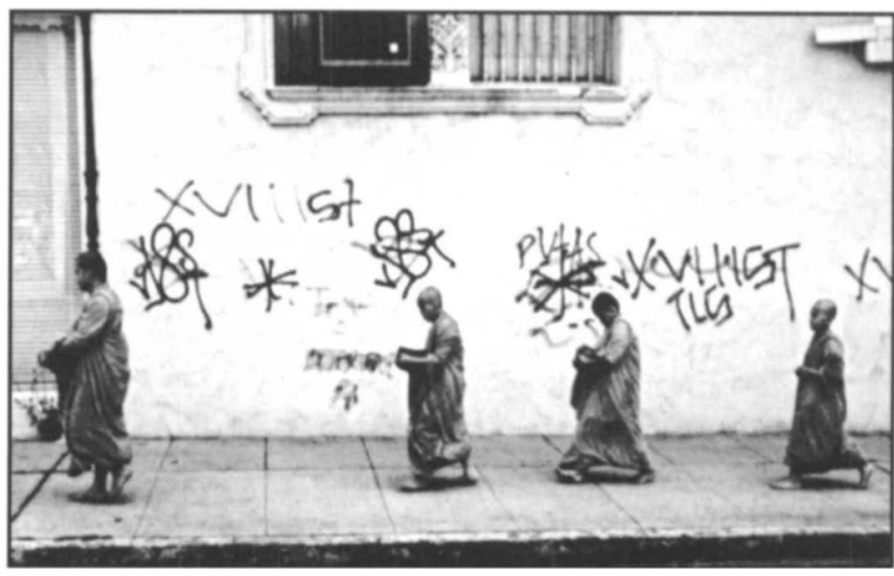

From The Faces of Buddbism in America

Congratulations

winners of the

1998 HIROMI ARISAWA AWARISS

\section{Contentious Traditions}

The Debate on Sati in Colonial India Lata Mani

"An important and disturbing book. Lata Mani has reopened the archives on widow burning in colonial India. ... Unsettling and illuminating." -Ranajit Guha, founding editor Subaltern Studies

$\$ 47.00$ cloth, $\$ 18.00$ paper, illustrated

\section{Geisha}

Liza Dalby

Back in print with a new preface- "The authoritative work on the geisha. It is filled with facts and history, shot through with insights and understanding."

$$
\text { - Japan Times }
$$

$\$ 17.95$ paper, illustrated

At bookstores or order 1-800-822-6657.

www.ucpress.edu



HELEN HARDACRE author of

Marketing the Menacing Fetus

A Pbilip E. Lilientbal Book

Twentieth-Century Japan, $\$ 35.00$ cloth, illustrated

LOUISE YOUNG apan's Total Empire

Manchuria and the Culture of Wartime Imperialism

A Study of the East Asian Institute. Columbia University, Twentieth-

Century Japan; $\$ 45.00$ cloth

UNIVERSITY OF CALIFORNIA PRESS 
AT BOOKSTORES, OR CALL (607) 277-2211 www.cornellpress.cornell.edu

\section{The Need}

\section{for Enemies}

A Bestiary of Political Forms

\section{F. G. BAILEY}

This book offers a ground-level view of regional politics in South Asia in the years following independence. In doing so, it analyzes political problems of a universal concern: incivility in public life, the inescapable dilemma of duty in tension with interests, and true believers contesting realists who see virtue in compromise. $\$ 39.95$ cloth, $\$ 15.95$ paper

\section{Booty Capitalism}

The Politics of Banking in the Philippines

\section{PAUL D. HUTCHCROFT}

In the postwar years, the Philippines seemed poised for longterm economic success, yet the country has been unable to convert its substantial developmental assets into developmental success. Even with the reforms of the mid-1990s, economic gains remain modest and short-lived. Paul D.

Hutchcroft addresses the political obstacles to Philippine development. 7 photos, 5 tables $\$ 39.95$

\section{Democracy at Work in an Indian Industrial Cooperative}

The Story of Kerala Dinesh Beedi T. M. THOMAS ISAAC, RICHARD W. FRANKE, AND PYARALAL RAGHAVAN

The authors tell the story of a democratic workers' cooperative that makes hand-rolled cigarettes in India. In 1969, workers in Kerala formed a beedi cooperative, creating an enterprise that continues to offer the best wages and benefits in the business, while making a profit and contributing to the local economy. AN ILR Press Book. A CORNELL INT'L REPORT. 1 map, 2 drawings, 10 photos $\$ 45.00$ cloth, $\$ 17.95$ paper

\section{CORNELL UNIVERSITY PRESS • SAGE HOUSE • 512 E STATE ST • ITHACA, NY 14850}

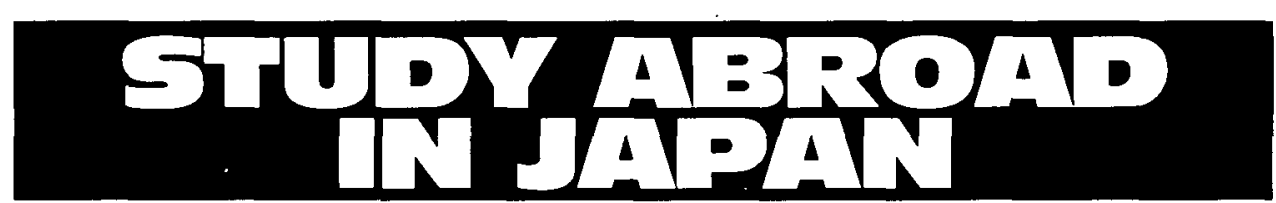

$\begin{array}{lllllllllllllllllllll}\text { T } & \text { E } & M & \text { P } & \text { L } & \text { E } & \text { U } & \text { N } & \text { I } & V & \text { E } & \text { R } & \text { S I } & \text { T } & \text { Y } & \text { J A } & \text { A } & \text { A } & \mathbf{N}\end{array}$

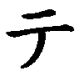

Spend a semester, summer or academic year studying in the heart of Tokyo at Temple University Japan. Choose from a broad range of courses taught in English including Asian Studies and Japanese language courses at all levels.

- Courses fully integrated with Japanese students

- Upper level courses in Art History, Asian Studies, Economics, Geography \& Urban Studies, History, Political Science, Psychology, Religion, and Sociology taught in English

1 Internships

- Japanese language study at beginning, intermediate, and advanced levels

\section{- Arranged housing}

For brochure and application, please contact:

Temple University International Programs

Conwell Hall, sth floor

1801 North Broad Street

Philadelphia, PA 19122

Telephone: 215 204-4684

E-mail: intlprog@vm.temple.edu or http://www.temple.edu/intlprog/ 


\section{NEW TITLES IN ASIAN STUDIES}

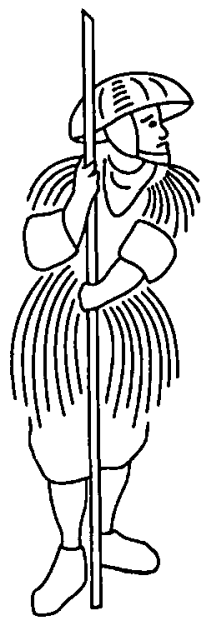

Even the Gods Rebel: The Peasants of Takaino and the 1871 Nakano Uprising in Japan, by Selçuk Esenbel

Even the Gods Rebe/ reexamines much of the history of nineteenth-century rural Japan through the lens of a single uprising. In this way, we learn about conflict, growth, community, political influence, administration, and the transition from Tokugawa to Meiji. By showing that the Nakano rebellion arose from the peasant tradition of communal uprisings, Esenbel has produced a powerful and original reinterpretation of the causes of change in rural Japan.

Monograph 57, ISBN 0-924304-38-3, 1998, 440 pages, cloth, List Price: \$38 (AAS Members: \$30)

\section{The Ming-Qing Conflict, 1619-1683: A Historiography and Source Guide, by Lynn A. Struve}

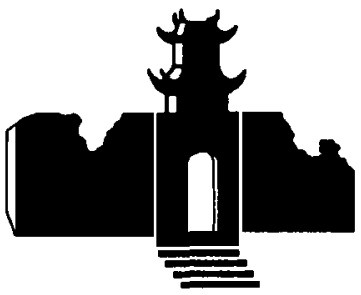

This exciting new resource is an indispensable aid for scholars and students of the late imperial period llate Ming through Oing dynasties). Part 1 ("A Sino-Cultural Historiography") features a 400-year intellectual history of Chinese interpretations of the Qing conquest. Part 2 ("The Best Primary Sources") presents a comprehensive annotated bibliography of resources available to scholars, including materials of Manchu, Japanese, Korean, and European origin. The annotations focus upon the origins of the physical texts as well as the potential biases they may contain.

Monograph 56, ISBN 0-924304-37.5, 1998, 448 pages, cloth, List Price: \$40 (AAS Members: \$32)

ORDERING INFORMATION

Payment may be made via a check (U.S. dollars) drawn on a U.S. bank or via MasterCard/Nisa.

\section{POSTAGE AND HANDLING}

For U.S. orders, add $\$ 4$ for the first book, $\$ 1$ for each additional. For non-U.S. orders, add $\$ 5$ for the first book, $\$ 2$ for each additional.
To place an order or receive a catalog. please contact:

ASSOCIATION FOR ASIAN STUDIES, INC. 1021 East Huron Street Ann Arbor, MI 48104 USA

Phone: 734-665-2490; Fax:734-665-3801

E-Mail: bookorder@aasianst.org 


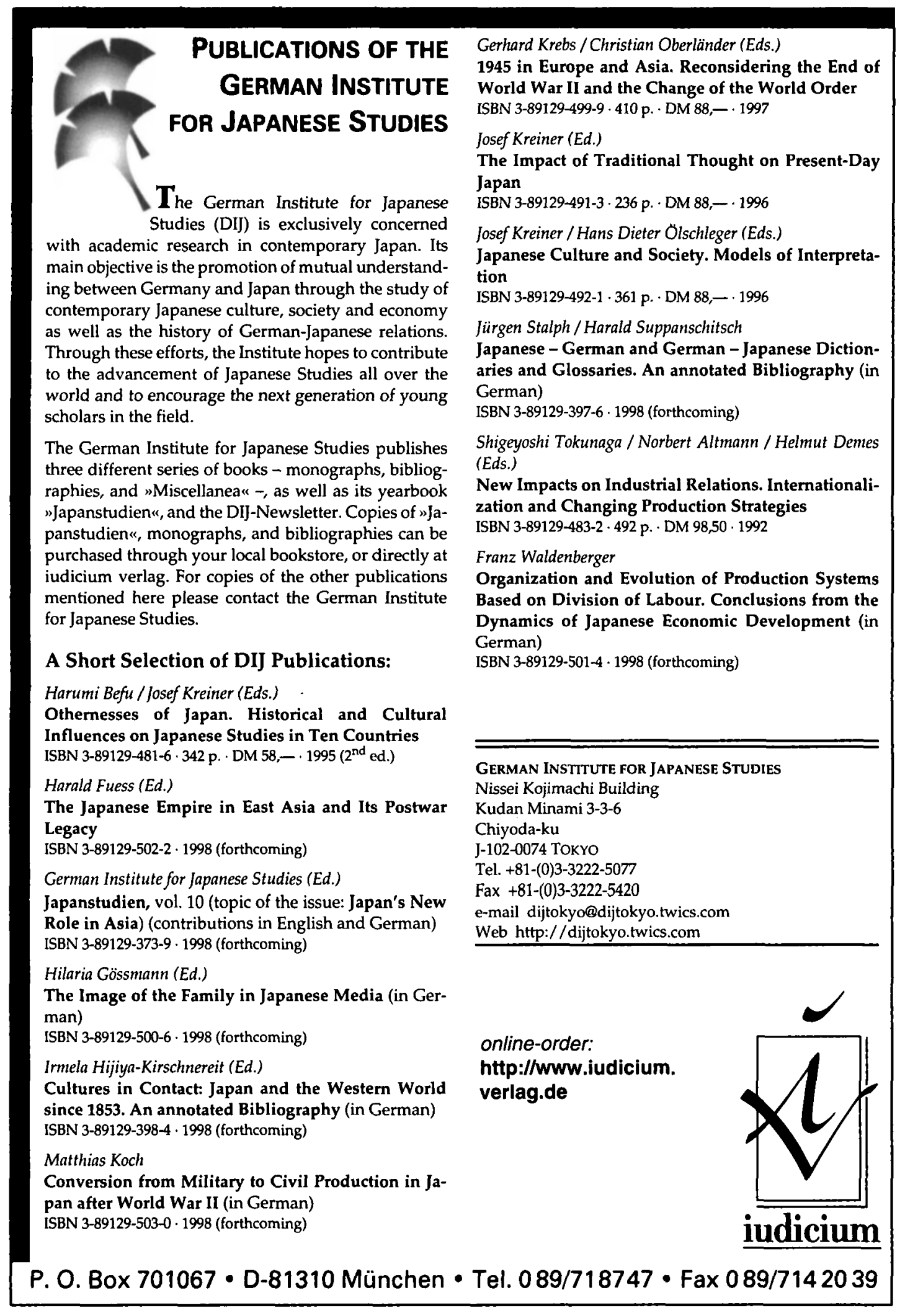




\section{IN RECOGNITION OF EXCELLENCE}

\section{IN SCHOLARLY PUBLICATION ON JAPAN,}

\section{THE ASSOCIATION OF AMERICAN UNIVERSITY PRESSES}

\section{CELEBRATES THE WINNERS OF}

\section{THE 1998 HIROMI ARISAWA MEMORIAL AWARDS}

Presented every two years to AAUP member presses for outstanding books on Japan, these Japanese-funded awards are intended to encourage the publication of high-quality scholarship in the field of Japanese studies. The cash prizes go to the publishers of the winning books, to be used to support the publication of further work in the field. The award-winning books are selecterd by a jury of distinguished scholars.

Bai Gao

ECONOMIC IDEOLOGY

AND JAPANESE

INDUSTRIAL POLICY

Combridge University Press

Helen Hardacre

MARKETINGTHE MENACING

FETUS IN JAPAN

University of California Press

Edward Kamens

UTAMAKURA, ALLUSION, AND INTERTEXTUALTTY

IN TRADITIONAL

JAPANESE POETRY

Yale University Press
Joan Piggott

THE EMERGENCE OF JAPANESE KINGSHIP

Stanford University Press

Louise Young

JAPAN'STOTAL EMPIRE:

MANCHURIA ANDTHE

CULTURE OFWARTIME

IMPERIALISM

University of California Press

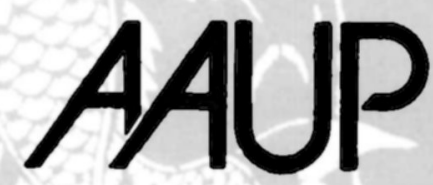

Association of American University Presses 584 Broadway, Suite 410, NY, NY 10012

(212) $941 \cdot 6610$ 


\section{Rowman $\&$ Littlefield}

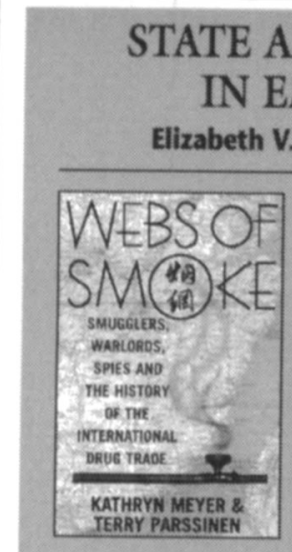

Alan Block, The Pennsylvania State University

WEBS OF SMOKE

Smugglers, Warlords, Spies,

and the History of the

International Drug Trade

By Kathryn Meyer and

Terry Parssinen

"Meyer and Parssinen write with

exceptional clarity, covering materi-

al that has never been adequately addressed. Together they have

written a masterful account of the

development of international drug

$\$ 19.95$ paper/ $\$ 29.95$ cloth

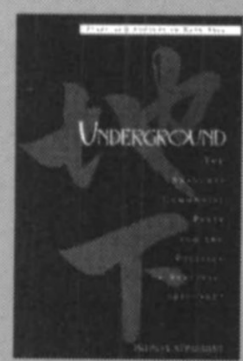

\section{UNDERGROUND}

The Shanghai Communist Party and the Politics of

Survival, 1927-1937

By Patricia Stranahan

"A rare double treat: a superb scholarly work - the first comprehensive history in the English language of a crucial phase in China's communist revolution- - that is

bound to impress a specialist read.

will engross readers with a weakness for tales of political

intrigue, heroism, betrayal, and survival in an extremely hostile

environment." - Michael Schoenhals, Lund University

$\$ 22.95 \mathrm{paper} / \$ 65.00$ doth

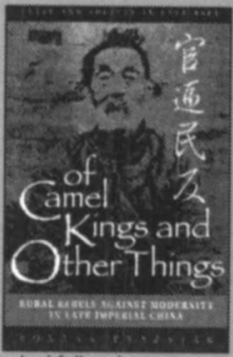

\section{OF CAMEL KINGS} AND OTHER

\section{THINGS}

Rural Rebels Against

Modernity in Late Imperial

China

By Roxann Prazniak

"A highly original exploration of an aspect of early twentieth-century

Chinese history that has too long

lacked full-scale treatment. The research is always impressive

and the work is pioneering."

-Emest P. Young, University of Michigan

$\$ 24.95$ paper/ $\$ 69.00$ cloth

For Orders

1-800-462-6420

Fax 1-800-338-4550

ASIAN VOICES

Mark Selden, Series Editor

\section{COMFORT WOMAN}

A Filipina's Story of Prostitution and Slavery under

the Japanese Military

By Maria Rosa Henson

"A compelling and moving account of one Filipina's ordeal under the japanese military. We are greatly enriched by this story and inspired by how one woman can overcome such epic suffering and still have such compassion and faith."

- Corazon C. Aquino

$\$ 19.95$ doth

\section{WIVES, MISTRESSES AND MATRIARCHS}

Asian Women Today

By Louise Williams

$\$ 17.95$ paper/ $\$ 69.00$ cloth

\section{COOPERATION OR CONFLICT IN THE TAIWAN STRAIT?}

By Ralph N. Clough

Explores the intractable differences between Beijing and Taipei over the status of Taiwan and the role of the United States.

$\$ 19.95$ paper/ \$54.00 cloth



CHINA'S FOREIGN RELATIONS By Denny Roy

$\$ 21.95$ paper/ \$64.00 cloth

MARKET ECONOMICS AND POLITICAL

\section{CHANGE}

Comparing China and Mexico

Timothy Cheek Edited by Juan D. Lindau and

"A unique undertaking and a delight. By putting Mexico and China side by side and setting the task of comparison in an entirely new context, the editors are able to tackle many of the old questions about political culture, political development, and state-society rela. tions in entirely new and original ways." - Timothy Brook, Stanford University

\$24.95 paper/ \$65.00 cloth

\section{THE EMPIRE OF THE TEXT}

Writing and Authority in Early Imperial China

\section{By Christopher Leigh Connery}

"A work of great brilliance and insight. This is scholarship at its best: skeptical, full of substance and ideas, not confined by conventional wisdom or fashionable trends."

-Victor H. Mair, University of Pennsylvania

$\$ 21.95$ paper/ \$65.00 cloth

Rowman \& Littlefield Publishers, Inc. 4720 Boston Way • Lanham, MD 20706

An Independent Publisher for the 21st Century 


\section{IJ I from cambridge}

\section{Now in paperback... \\ The Sikhs of the Punjab \\ J.S. Grewal \\ "J. S. Grewal's book is an extremely valuable reference work for Sikh and Punjabi history from Guru \\ Nanak's day down to the present." \\ -American Historical Review \\ The New Cambridge History of India Il:3 \\ 0-521-63764-3 Paperback \$24.95}

\section{The Untouchables}

Subordination, Poverty and the State

in Modern India

Oliver Mendelsohn and

\section{Marika Vicziany}

In a compelling account of the lives of those at the bottom of Indian society, the authors explore the construction of the Untouchables as a social and political category, the historical background that led to such a definition and their position in India today. Contemporary South Asia 4
$0-521-55362-8$
Hardback
$\$ 59.95$
$0-521-55671-6$
Paperback
$\$ 22.95$

\section{Mercantilism in a Japanese Domain}

The Merchant Origins of Economic Nationalism in 18th-Century Tosa

\section{Luke S. Roberts}

"Luke Roberts' research is at the cutting edge of scholarship on Tokugawa Japan. His analysis of the formation of economic policy in an eighteenth-century domain has important consequences for consideration of class dynamics, political consciousness, and proto-nationalism in early modern Japan."

-Marius Jansen, Princeton University

0-521-62131-3 Hardback \$59.95

\section{Building Social Capital in Thailand}

Fibers, Finance, and Infrastructure

\section{Danny Unger}

This book examines the recent rapid economic expansion in Thailand, and in Southeast Asia more generally. In a highly original argument, Unger considers the unique organization of Thai society, and the impact this has had on the country's institutions, and their political and economic outcomes. Unger takes an interdisciplinary approach, building on the literatures of social capital and embedded autonomy. Cambridge Asia-Pacific Studies
$0-521-63058-4$ Hardback
0-521-63931-X Paperback
$\$ 59.95$
$\$ 19.95$

\section{Forging Reform in China}

The Fate of State-Owned Industry Edward S. Steinfeld

"This penetrating, pioneering analysis of several large Chinese steel companies, offers an inside account of the enormous problems of China's state enterprises. Ed Steinfeld shows the logic of how state enterprises that show profits' and pay taxes bave remained inefficient despite reforms."

-Ezra Vogel, Harvard University Cambridge Modern China Series

0-521-63335-4 Hardback \$44.95

\section{Britain, Southeast Asia and the Onset of the Cold War, 1945-50 Nicholas Tarling}

This detailed and original study throws new light on the evolution of British policy in Southeast Asia in the turbulent postwar period. Extensive archival research and insightful analysis of British policy demonstrate that Southeast Asia was perceived as a region consisting of mutually cooperating new states, rather than a fragmented mass.

$0.521 .63261 .7 \quad$ Hardback $\$ 64.95$

\section{Commodifying Communism}

Business, Trust, and Politics in a Chinese City David L. Wank

"China's transition to market-oriented socialism comes alive in this theoretically sophisticated, yet empirically focused ethnography. I wholeheartedly recommend this first-rate book to anyone who wants to know how the Chinese business really works."

-Gary Hamilton, University of Washington Structural Analysis in the Social Sciences 14

0-521-62073-2 Hardback \$59.95

\section{Deadly Dreams}

Opium and the Arrow War (1856-1860)

in China

\section{J.Y. Wong}

Many have accepted that the Arrow War (1856-60) was caused by an insult to the British flag belonging to the pirate boat Arrow. Dr. Wong argues that Britain's reliance on the opium trade with China played a far greater role in pushing the diplomatic conflict into war. The war was not a simple diplomatic squabble: it involved vital economic interests in British India, which had to be protected at all costs. Dr. Wong offers penetrating insights into theories of imperialism and how they might be reassessed. Cambridge Studies in Chinese History, Literature and Institutions

0-521-55255-9 Hardback \$69.95 


\section{New in Asian Studies from HarperCollins Publishers}

"I don't quite know how Jeffery Paine has done it...but Father India is an utterly surprising and indispensable book. It equally animates the punishing and joyful history of India, all through the lens of Western literature." - Howard Norman, author of The Bird Artist

$\mathcal{F}_{\text {ing influence of the subcontinent on }}^{\text {ather }}$ Western ideas of modernity through the spellbinding stories of a succession of 20th-century Westerners - including E. M. Forster, Carl Jung, W.B. Yeats, Christopher Isherwood, V. S. Naipaul, and Martin Luther King, Jr. — who acted out their most secret dreams in India. hardcover $\$ 25.00 \quad 0-06-0173033$



"Few books in recent years, if any, offer such a comprehensive overview of what ails India... and few writers benefit so obviously from the perspective Tharoor offers, that of an Indian with a profound empathy for his native culture...and the insight [from] following India's progress from afar."

-New York Times

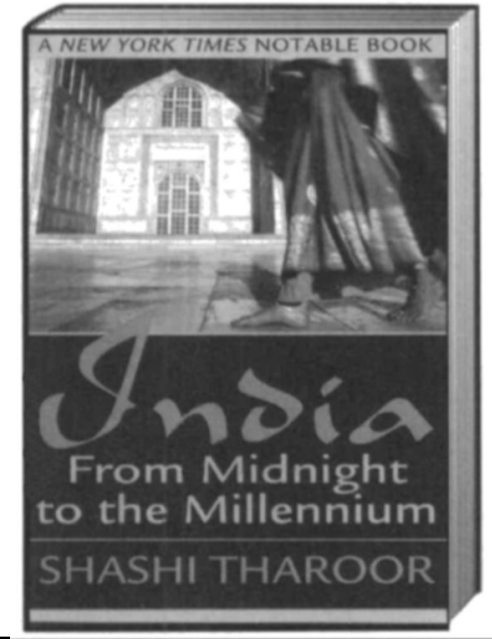

Published to widespread acclaim in hard $P$ cover, India: From Midnight to Millennium examines the startling progress of this energized and enigmatic nation fifty years after gaining its independence from British colonialism, and assesses the serious complexities and challenges India faces in the next century.

paperback $\$ 14.00 \quad$ 0-06-097753-1

HarperCollinsPublishers 







\section{The Book in Japan}

\section{A Cultural History from the Beginnings to the Nineteenth Century}

\section{Peter Francis Kornicki}

This study deals with all aspects of the history of the book in Japan, from the production of manuscripts and printed books to book-collecting, libraries, censorship and readership. It also sets books in the context of Japan's cultural ties with China, Korea and Parhae.

The focus is on the history of both texts and physical books. This encompasses not only books in Japanese but also books in Chinese by Chinese and Korean authors, and some Western books as well.

It is an essential reference tool and bibliographic guide for all those interested in book studies, and particularly of importance for historians of Japanese culture. It is illustrated with examples taken from various collections of early Japanese books in Europe.

Readership: All graduate students and scholars specialising in the study of pre-modern Japanese history of literature; librarians in general and specialists in the history of the book in general.

Peter Francis Kornicki, Ph.D. (1979), University of Oxford, is Reader in Japanese History and Bibliography at the University of Cambridge. He has published Early fapanese Books in Cambridge University Library (1991) and co-edited the Cambridge Encyclopedia of fapan (1993).

- Publication date:1998. (xviii, 498 pp., 23 illus.)

- ISBN 9004101950

- Cloth NLG 168.- / uss 99.-

- Price for subscribers to the series NLG 152.- / US\$89.50

- Handbook of Oriental Studies. Part 5. Japan, 7

Brill Academic Publishers

P.O. Box 9000

2300 PA Leiden

The Netherlands

Brill Academic Publishers Inc. 


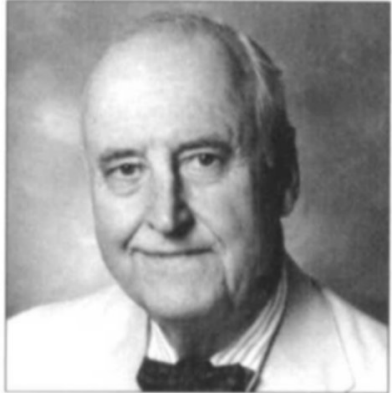

\section{ASIAN VALUES AND HUMAN RIGHTS \\ A Confucian \\ Communitarian \\ Perspective \\ WM.THEODORE DE BARY}

In this provocative book, one of our most learned scholars of China

moves beyond the political shouting match surrounding human rights in

China by contextualizing this debate from a Confucian and a historical

perspective. Highlighting the philosophical development of

Confucianism as well as the Chinese

historical experience with

community organization,

constitutionalism, education, and

women's rights, de Bary argues that while the Confucian sense of personhood differs in some respects from Western libertarian concepts of the individual, it is not incompatible with human rights.

$\$ 27.95$ cloth

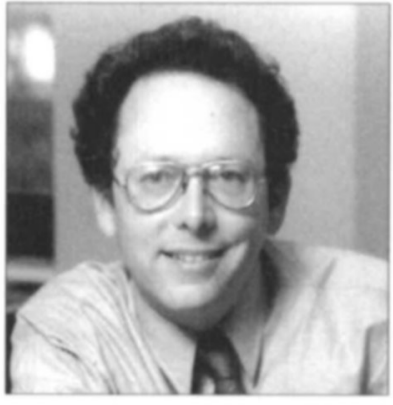

THE WACES OF AFFLUENCE

Labor and Management in Postwar Japan

\section{ANDREW GORDON}

Andrew Gordon goes to the core of the Japanese enterprise systemthe workplace-and reveals a complex history of contest and confrontation. Though the Japanese

model produced a dynamic economy, managerial hegemony was achieved only after a bitter struggle that undermined the democratic

potential of postwar society.

Beginning with the Occupation reforms and their influence on the workplace, Gordon traces worker activism in the 1950s and '60s, and how it gave way to management victory in the 1960s and 70 s. He illuminates the Japanese system with frequent references to other capitalist nations, and looks to Japan's future, rebutting hasty predictions that Japanese industrial relations are about to be dramatically transformed in the American free-market image. $\$ 35.00$ doth

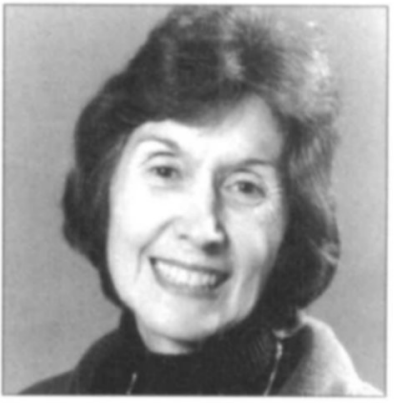

CHINA

A New History

Enlarged Edition

JOHN KING FAIRBANK AND MERLE GOLDMAN

The late John King Farbank was the

West's doyen on China, and this book is the full and final expression of his lifelong engagement with this vast ancient civilization. This book remains a masterwork without

parallel-a concise and

authoritative account of China and its people over four millennia. The distinguished historian Merle

Goldman has brought the book up to date with a chapter on events in the post-Mao period and a new preface and epilogue.

'This new edition is supert. The interpretative themes structuring Goldman's conduding chapter are strong and convincing. Illuminating comparisons are drawn between the Deng Xiaoping and earlier eras." -Paul A. Cohen, Wellesley College Belknap Press 60 halftones $\cdot 624$ pages $\$ 16.95$ paper $\cdot \$ 35.00$ doth 


\section{The Bibliography of Asian Studies-ONLINE}

Starting July 1, 1998, the single most important record of research and scholarly literature on Asia written in Western languages will be available ONLINE via library subscription . . .

- Full content of the annual printed Bibliography of Asian Studies from 1971-1991, plus numerous citations from more recent years lincluding all articles in the 100 most-used journals in Asian studies)

- Approximately 420,000 citations that can be searched within seconds and easily downloaded and printed

- Entries accessible by subject, country, journal title, or key word

- 1000s of new entries added every three months

- Accessible to faculty, staff, and students at subscribing colleges and universities via their computer systems, with validation by IP address

Librarians who have had a chance to try the online BAS testify that it provides far better access to Western language materials on Asia than anything previously available

Further details, subscription prices, and an order form are available at:

\section{http://www.aasianst.org}

Or you may contact: BAS Online Subscriptions, Association for Asian Studies,

1021 East Huron Street, Ann Arbor. MI 48104 USA

Tel: 734-665-2490; Fax: 734-665-3801

E-Mail: bassub@aasianst.org 


\section{OXFORD UNIVERSITY PRESS}

\section{NUCLEAR WEAPONS AND ARMS CONTROL IN SOUTH ASIA AFTER \\ THE TEST BAN}

\section{Edited by ERIC ARNETI}

This book studies internal politics and policies toward nuclear-weapons reduction in a part of the world where arms control is almost non-existent: China, India, and Pakistan. It considers the implications of conventional arms transfers-and especially of Indias strategic-defense moves-for nuclear stability. (SIPRI Research Reports 14)

1998112 pp. paper $\$ 24.50$ cloth $\$ 47.50$

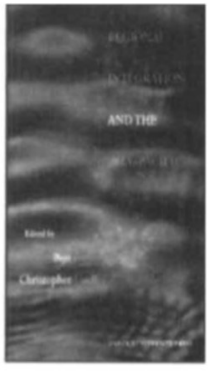

\section{New in paperback! \\ REGIONAL \\ INTEGRATION AND THE ASIA-PACIFIC Edited by BIJIT BORA and CHRISTOPHER FINDLAY \\ "A comprehensive and informa- tive reference book on the new architecture of the world trading system."-The Journal of Asian Studies 1996 (paper 1998) $272 \mathrm{pp}$ poper $\$ 32.00$ cloth $\$ 85.00^{\circ}$}

\section{ASIA'S COMPUTER CHALLENGE} Threat or Opportunity for the United States and the World?

JASON DEDRICK and KENNETH L. KRAEMER

"Dedrick and Kraemer offer a sweeping empirical analysis of the rise of the computer industry in Asia. They bring to life one of the great challenges facing American technology companies in the years to come."-David B. Yoffie, Harvard Business School 1998384 pp. $\$ 39.95$

\section{ANTHROPOLOGY AND DEVELOPMENT IN SOUTH-EAST ASIA \\ Theory and Practice VICTOR T. KING}

King provides the first text on South-East Asia to examine the relations between anthropology and development in both their theoretical and practical dimensions. He covers several anthropological contributions to development, citing case-studies in such areas as resettlement, tourism, health care, gender, and ecology.

(South-East Asian Social Science Monographs) $1998 \quad 320$ pp. $\$ 44.00$

\section{ECONOMIC AND SOCIAL} PROGRESS IN ASIA

Why Pakistan Did Not Become a Tiger OMAR NOMAN

"Noman pulls it off....A good job of creating a picture of history and a story around it that hangs together [and is] well-written.... Noman has rendered researchers in this area a service... This book is a welcome addition and will be around for some time." -The Nation (Pakistan)

(The Jubilee Series)

$1998 \quad 340$ pp. $\$ 35.00$

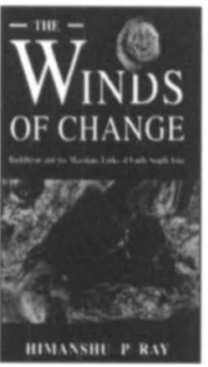

\section{New in paperback! THE WINDS OF CHANGE}

Buddhism and the Moritime Links of Early South Asia HIMANSHU P. RAY

This is a pioneering study that challenges the conventional view about the importance of Roman and Arab seafarers to maritime trade in South Asia. It argues that Buddhism provided the structure necessary for the remarkable

upsurge in trade for the period $400 \mathrm{BC}$ to AD 400 . To this end, Ray employs archaeological, literary, and ethnographic evidence, much of it unpublished. 1995 (paper 1998) $256 \mathrm{pp}$. paper $\$ 11.95$ doth $\$ 29.95$

\section{GROWTH TRIANGLES IN ASIA}

\section{A New Approach to Regional}

Economic Cooperation

Second Edition

Edited by MYO THANT, MIN TANG, and HIROSH KAKAZU

The "growth triangle" is a newly popular form of regional economic cooperation in Asia that involves bringing together the resources of three countries to collectively foster economic development in each. In studying three such triangles-in southern China; on the borders of Singapore, Indonesia, and Malaysia; and in the Tumen River Delta on China's northeast border-these essays define, explore, and debate the issues surrounding the establishment of such entities.

1998468 pp. $\$ 72.00$

\section{HARBINGERS OF RAIN}

Land and Life in South Asia

\section{A. R. VASAVI}

This book affords a better understanding of the cultural implications of government-enforced programs in agrarian societies. As demonstrated here, the introduction of new agricultural techniques, new crops, and new conceptualizations of droughts leads not only to economic and political changes, but also to changes in the social patterns and symbols of a sociery. $1998 \quad 272$ pp. $\$ 17.95$

\section{THE ARCHITECTURE OF SOUTH-EAST ASIA THROUGH TRAVELERS' EYES}

Edited by ROXANA WATERSON

With a Foreword by VICTOR T. KING

Gathered here for the first cime are the best of the older travel writings about the diverse and often amazing architectural works of South-East Asia-and the cultures and lifestyles that went with them. From ruined temples to royal palaces, from remote rural villages to bustling cities like Singapore, these vivid observations make for much fascinating reading.

(Oxforl in Asia Paperbacks)

$1998336 \mathrm{pp}$. poper $\$ 19.95$

Prices are subject to change and apply only in the US.

To order, or for more information, please call 1-800-451-7556. In Canada, call 1-800-387-8020 HTTP://WWWOUP-USA ORG 


\section{旭 The NEW Sunrise 98 software for Chinese features:}

- Newv: No more split Hànzi. "Framing Error" 100\% eliminated !!!

- New "Pinyin with Hànzi" mode now available: Pīnyinn text entered without tones automatically converts to tone-marked Pinyin, with the corresponding Hànzi aligned beneath the Pinyin text !!!

- Nevv: "Save as HTML" one-click Web publishing of Chinese text.

- Nevv: 200.000+ entry Chinese-English-Chinese online dictionary.

- Newv: Works with Win95/98/NT MS Office 97, Corel WP 7/8, etc.

- Easy Input: Pinyiñ 拼音, zhìyin fúhào 注音符號 to Hànzi 漢字.

- Text-To-Speech: your multi-media computer reads Chinese aloud.

- Allows mixing English etc., Chinese 繁體, 简体, Japanese, Korean.

- CJK network version for your computer lab, special rates, inquire! Shareware Academic Version from $\$ 39 .^{00}$ Professional Version $\$ 495 .^{00}$

For your CJK needs, go http://www.cjkware.com

The official Web site (with on-line store) of AsiaCom, Montreal \& Ottawa Developers of the pioneering XīnTiānMă 新天馬 system



E-mail: risingsun@msn.com Mail: AsiaCom Box 535, Stn. B Ottawa, Ontario Canada K1P 5P6

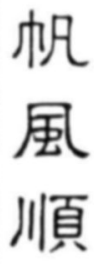

\section{MUSEUM QUALITY EXHIBITS}

"MY LIFE IS MY MESSAGE"-40 panels $(2$ ' $x$ 4') of photographs with captions on the life of Mahatma Gandhi.

"INDIA-THE PEOPLE AND THEIR LAND"-more than 100 color photographs taken over 40 years by Beatrice Pitney Lamb.

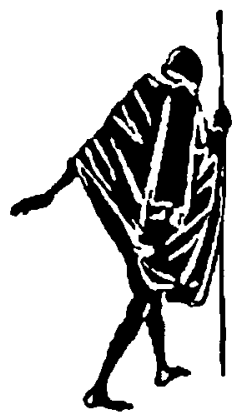

"BEAUTY IN STONE"-Hindu, Buddhist, and Islamic architecture of India, color photographs by Beatrice Pitney Lamb.

Also smaller portable exhibit (sent by mail), video-cassettes (including biographical documentaries of Gandhi), and other resources available for loan.

Undergraduate-level CORRESPONDENCE COURSE on Gandhi (study materials from the Gujarat Vidyapith University in India founded by him in 1920).

Call or write: THE GANDHI MEMORIAL CENTER

P. O. Box 9515

Washington, D.C. 20016

(301) 229-3871 
Susan Blader

Tales of Magistrate Bao and

His Valiant Lieutenants

Selections from Sanxia Wuyi

This story of murder, mystery, and courtroom drama revolves around the famed Song dynasty magistrate, Bao Zheng, the quintessential incorruptible government official.

CUP, paper $\$ 26.50$

\section{Oōka Shōhei}

The Shade of Blossoms

Translated with an Introduction by Dennis Washburn

“... depicts the atmosphere and social mores of Tokyo's decadent Ginza District of the 1950s through the haunting story of an aging nightclub courtesan. ... Despite the irony of Shōhei's prose, there is great pathos in this story of the little bar hostess whose circumstances overwhelm her." - Publishers Weekly

CJS, cloth \$28.95, paper \$12.95

Hitomi Tonomura, Anne Walthall, and Wakita Haruko, Editors

\section{Women and Class in Japanese History}

Studies the critical linkages between the meaning of female domains and the workings of other social institutions.

CJS, cloth $\$ 44.95$

Steve Rabson

Righteous Cause or Tragic Folly Changing Views of War in Modern Japanese Poetry

"Provocative and stimulating. War poetry, whether Eastern or Western, has rarely been probed so skillfully." - John Bradley, Northern Illinois Universiry

CJS, cloth $\$ 36.95$

\section{Maria Galikowski}

\section{Art and Politics in China, 1949-1984}

Discusses the major stages of development in Chinese art after 1949 .

CUP, paper $\$ 29.95$
Bernard Grofman, Sun-Chull Lee, Edwin Winckler, and Brian Woodall, Editors

Elections in Japan, Korea, and Taiwan under the Single Non-Transferable Vote The Comparative Study of an Embedded Institution

A look at the impact of the single-vote rule on electoral competition in Japan, Korea, and Taiwan.

cloth $\$ 74.50$

\section{Roy W. Bahl, Jr.}

\section{Taxation Reform in China}

An analysis of China's 1994 tax reform and its role in the attempted modernization of China's fiscal system.

Distributed for The 1990 Institute cloth $\$ 39.50$

\section{BACK IN PRINT}

Shen Tong with Marianne Yen

\section{Almost a Revolution}

The Story of a Chinese Student's Journey from Boyhood to Leadership in Tiananmen Square

New Preface and Epilogue by the Author

... an important contribution to China's newly discovered historical memory."

-New York Times Book Review

paper $\$ 19.95$

Richard Rutt, Editor and Translator

The Bamboo Grove

An Introduction to Sijo

With a New Preface by the Translator Introduction by David R. McCann

Richard Rutt's skillful translations of the most popular of all Korea's traditional poetic forms.

paper $\$ 15.95$

CJS Distributed for the Center for Japanese Studies, University of Michigan

CUP Distributed for the Chinese University Press

For further information, please check our website at www.press.umich.edu

Credit card buyers may order by phone (734-764-4392) or by fax (800-876-1922).

The University of Michigan Press Dept. CF

Ann Arbor, Michigan 48106-1104 


\section{DEPARTMENT OF JAPANESE STUDIES}

Applications are invited for teaching appointments in the Department of Japanese Studies from candidates who possess a relevant $\mathrm{PhD}$ degree and have teaching/ research interests in the following areas:

(1) Japanese language and linguistics

(2) Japanese business and economics

(3) Japanese political economy and international relations

Established in 1981, the Department is one of the largest Japanese Studies departments in the Asia-Pacific region, providing a multi-disciplinary approach to the study of Japan, including such areas as language and linguistics, society and culture, business and economics, politics and international relations, history and literature, and art and aesthetics. With a current strength of 20 full-time staff, 20 part-time language instructors and over 900 students, the Department emphasises excellence in research and teaching.

NATIONAL UNIVERSITY<smiles></smiles>

\section{SINGAPORE}

The Department's main research focus is on the Asian dimension of Japanese studies, especially Japanese-Chinese studies and Japanese-Southeast Asian studies. Funding for research is available, and many staff have published in major international journals and academic presses. The University and Department also have good Japanese resource collections totalling more than 26,000 Japanese books, 175 periodicals and numerous audio-visual materials.

Besides appointments on normal 3-year contracts, visiting appointments for one or two years will also be considered.

Gross annual emoluments range as follows:

Level of Appointment Salary Range

Assistant Professor $\$ \$ \$ 8,800-87,600 /(90,720-100,440)$

Associate Professor $\$ \$ \$(84,360-100,440) / 125,640-144,360 /(149,760-177,840)$

Professor

$S \$ 149,760-211,200$

(US $\$ 1.00=\$ \$ 1.74$ approximately)

In addition, a 13th month Annual Allowance and an Annual Variable Component may be payable at year end, under the flexible wage system, to staff on normal contracts. The commencing salary will depend on the candidate's qualifications, experience and the level of appointment offered.

Leave and medical benefits will be provided. Depending on the type of contract offered, other benefits may include: provident fund benefits or an end-of-contract gratuity, a settling-in allowance, subsidised housing, education allowance for up to three children subject to a maximum of $\$ \$ 16,425$ per annum per child, passage assistance and baggage allowance for the transportation of personal effects to Singapore. Staff members may undertake consultation work, subject to the approval of the University, and retain consultation fees up to a maximum of $60 \%$ of their gross annual emoluments in a calendar year.

All academic staff will be given a networked personal computer with access to a Cray supercomputer, UNIX hosts, departmental laser printers, a wide spectrum of software, on-line library catalogue, CD-ROM databases, Video-on-Demand, INtv and Internet.

Application forms and further information on terms and conditions of service may be obtained from:

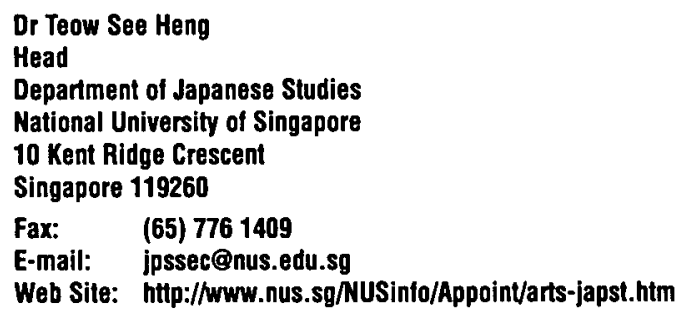

Only shortlisted candidates will be notified. 


\section{Now available in paperback \\ ASIA IN THE MAKING OF EUROPE Volume III: A Century of Advance

\author{
DONALD F. LACH and EDWIN J. VAN KLEY
}

\section{A New York Times Book Review Notable Book of the Year}

T Wis monumental series, acclaimed as a "masterpiece of comprehensive scholarship" in the New York Times Book Review, reveals the impact of Asia's high civilizations 1 on the development of modern Western society. The authors examine the ways in which European encounters with Asia have altered the development of Western society. art, literature, science, and religion since the Renaissance.

In Volume III: A Century of Advance, the authors have researched seventeenth-century European writings on Asia in an effort to understand how contemporaries saw Asian societies and peoples.

Book 1: Trade, Missions, Literature discusses Christian missions and trade and conquest in the East. It examines the various histories, reports, letterbooks. and travelogues printed and widely disseminated throughout Europe in the seventeenth century. Individual chapters cover literature from Iberia, Italy, France, the Netherlands, Germany, Denmark, and England.

Book 2: South Asia examines the European images of the lands, societies. religions, and cultures of the Mughul Empire, Goa, Bijapur, Kanara, Malabar, Coromandel, and insular South Asia including the Maldive and Laccadive Archipelagoes and Ceylon.
Book 3: Southeast Asia examines European images of the lands, societies, religions, and cultures of Southeast Asta. The continental nations of Siam, Vietnam, Malaya, Pegu, Arakan. Cambodia, and Laos are discussed, as are the islands of Java, Bali, Sumatra, Borneo, Amboina, the Moluccas, the Bandas, Celebes, the Lesser Sundas, New Guinea. Australia, New Zealand, the Philippines, Mindanao. Jolo, Guam. and the Marianas.

Book 4: East Asia examines European images of China during the late Ming and early Ch"ing dynasties, ranging from its religious practices, customs, and intellectual life to its geography and climate. Additional chapters discuss Japan. Tibet. Korea, Taiwan, and Inner Asia. This book also contains an epilogue to the entire third volume, as well as bibliographies and the cumulative index.
Book 1: Trade, Missions, Literature Paper 535.00660 pages 90 halittones, 17 line drawings. 2 map, 4 tables
Book 2: South Asia Paper 530.00604 pages 84 halftones, 17 line drawings, 6 maps, 5 tables
Book 3: Southeast Asia Paper \$28.00 524 pages 69 halftones, 9 line drawings, 4 maps
Book 4: East Asia Paper $\$ 35.00640$ pages 130 halttones, 21 line drawings, 2 maps

The University of Chicago Press 5801 South Eilis Avenue, Chicago it 60637 


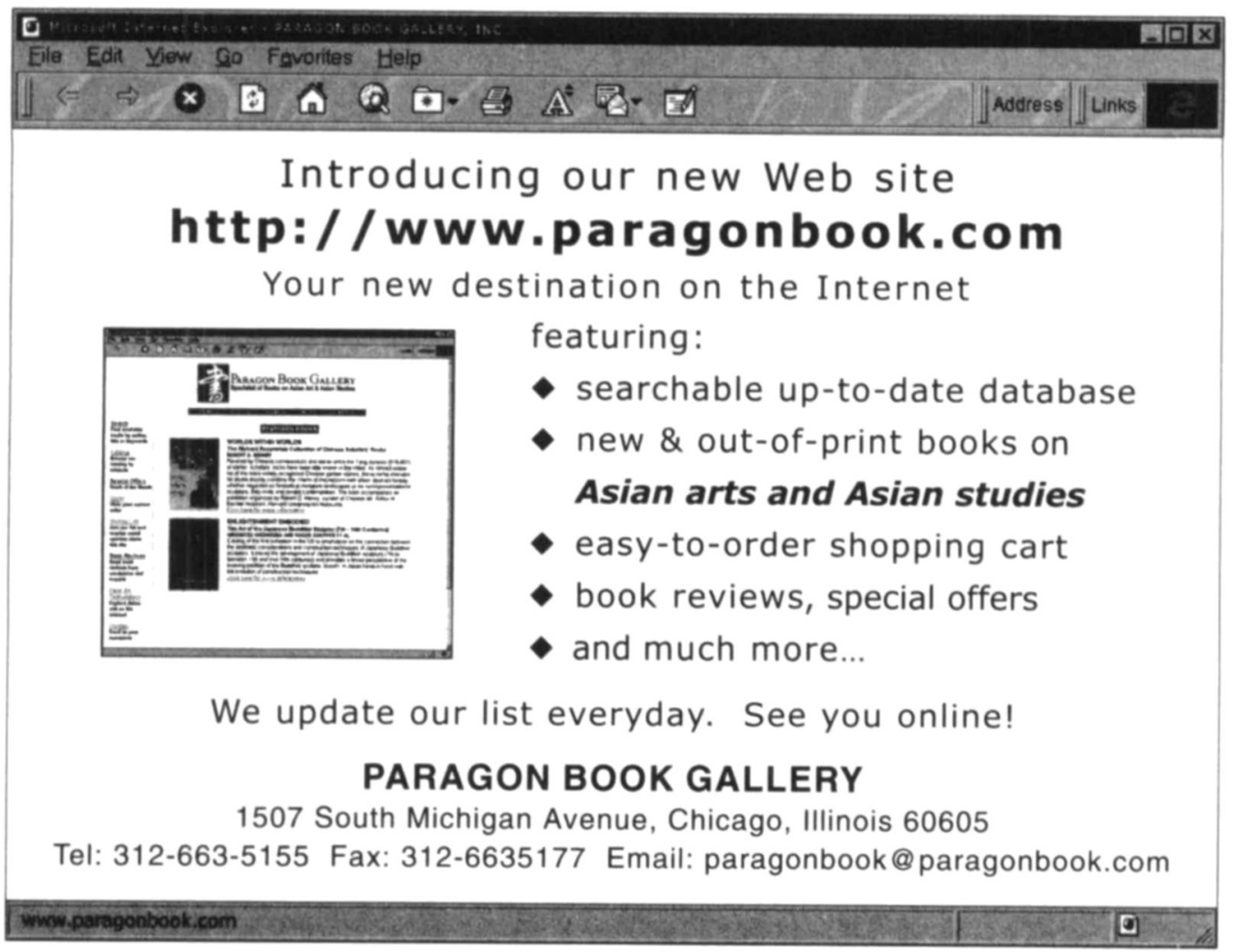

\section{INFORMED SOURCES}

\section{CHINA DOCUMENTS ANNUAL}

Edited by Peter R. Moody, Jr.

The vital decrees, speeches, laws and other primary sources needed for informed teaching and research, critically selected and prepared by a leading authority.

Vols 1-6 (1989-1994) in print. Vol. 7 The Consolidation of Reform due 1999.

All volumes contain Introductions, headnotes to each document, annotation, bibliographies, name, place, institution, subject indexes. In English.

$\$ 77$ subscription / $\$ 97$ non-subscription.

Peter R. Moody, Jr., is Professor in Government and International Studies at the University of Notre Dame.

\section{CHINA FACTS \& FIGURES ANNUAL}

\section{Edited by James Mulvenon}

Accumulates annually in English all basic and statistical information about the PRC, based on current data from official, private, international and scholarly sources organized into thirty major categories across a wide spectrum of subjects.

Vols. 1-23 (1978-1998) of this respected reference number more than 8000 pages, an incomparable database containing thousands of entries, tables, charts, figures. Each volume contains all new data. Sources cited.

$\$ 77$ subscription / \$97 non-subscription.

"Belongs in all China collections....all libraries."-Choice

James Mulvenon is a research consultant at the RAND Corp.

ACADEMIC INTERNATIONAL PRESS • POB 1111C • Gulf Breeze FL 32562

8509325479 (fax) • aipress@aol.com·http://sites.gulf.net/aip/ 


\section{MONOGRAPHS FROM AAS}

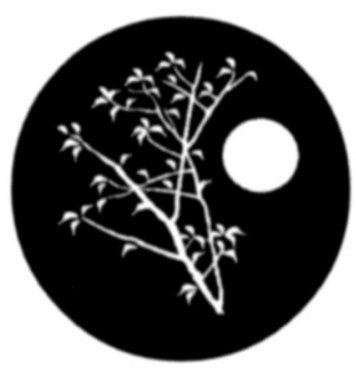

Records of Wind and Earih: A Translation of Fudoki, with InIROduction and COMMENIARIES by Michiko Y. Aoki In A.D. 713, the Japanese central government ordered all provincial governors to compile surveys of their respective regions, including products, animals, plants, land conditions, etymologies of place names, legends, and oral traditions. The five extant "old" fudoki translated in Records of Wind and Eartb are all that remain of these early reports. Three of these fudoki (Harima, Bungo, and Hizen) are being made available here for the first time in English. This collection contains invaluable records for any English-speaking person wishing to understand the early history of Japan-its land, its people, and its earliest literature.

Monograph 53. ISBN 0-924304-32-4, 1997, 364 pages, cloth. List price: $\$ 36$ (AAS Members: $\$ 29.00$ )

\section{River of Sorrow: Environment and Social}

\section{Control in Riparian Norih India, 1770- 1994}

by Christopher V. Hill

In this analysis of colonial attempts to control and manage the agrarian region surrounding the Kosi River, Hill argues that colonial ecological, political, and social policies were inextricably intertwined. The colonial administrators set about "improving" India's physical environment, just as they "improved" its social and political climate. In so doing, they were ill-prepared to understand, let alone administer, a river such as the Kosi-which traced a violent and erratic course out of the Himalayas, "carrying

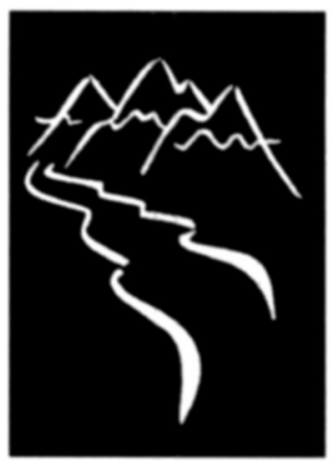
thousands of tons of silty sand and destroying everything in its path." The ecological paternalism imposed by the colonial governors introduced social and revenue policies that were to have a profound effect on the peasantry that continues to this day.

Monograph 55. ISBN 0-924304-36-7. 1997, 216 pages, cloth. List price: $\$ 33$ (AAS Members: $\$ 26.50$ )

\section{ORDERING INFORMATION}

Payment may be made via a check (U.S. dollars) drawn on a U.S. bank or via MasterCard/Visa.

\section{POSTAGE AND HANDLING}

For U.S. orders, add $\$ 4$ for the first book, $\$ 1$ for each additional. For non-U.S. orders, add $\$ 5$ for the first book, $\$ 2$ for each additional.
To place an order or receive a catalog, please contact:

\section{ASSOCIATION FOR ASIAN STUDIES, INC.}

1021 East Huron Street

Ann Arbor, MI 48104 USA

Phone. 734-665-2490, Fax:734-665-3801

E-Mail: bookorder@aasianst.org 
香港中文大學 中國文化研究所

古文獻資料庫中心

THE CHANT CENTER

announces the release of

\section{A COMPLETE DATABASE of CHinese ANcient Texts}

on the web, on CD-ROM/Floppy, and in a 50-volume plus concordance series.

Features of the database include:

- All texts emended and edited by our own expert teams.

- Detailed and complete notes on all emendations.

- The use of our own, carefully researched character sets for all texts.

- Full Boolean search on all texts or any combination of texts.

- A long term project started in 1988 under the support of the Hong Kong Research Grants Council (RGC) and the CCK Foundation of Taiwan.

A significant portion of the CHANT Database is FREE, and an initial subscription of US\$100/yr-seat (US\$150 for institutions) will bring unrestricted access to the following:

- All 900 titles of traditional texts (傮世文教) from antiquity up to $589 \mathrm{AD}$, $32 M$ characters, to be released by phases during 1999.

- 9 titles of texts on bamboo/silk (什简帛書), $1.2 \mathrm{M}$ characters, and the COMPLETE Shang oracular bone inscriptions (甲骨卜触), $1 M$ characters, to be released by phases during 2000 .

- Zhou bronze inscriptions (金文), $0.2 \mathrm{M}$ characters, will be available by the early 2000's.

\section{VISIT OUR WEBSITE at http://www.chant.org AND FIND OUT ABOUT THE DETAILS}

The CHANT Center is an integral part of

The Institute of Chinese Studies

The Chinese University of Hong Kong, Shatin, Hong Kong

Tel. : (852) $26097381 \quad$ Fax : (852) $26035149 \quad$ E-mail : chant@cuhk.edu.hk 


\section{New of COLUMBIA}

\section{TWO FROM DONALD KEENE}

\section{MODERN}

\section{JAPANESE DIARIES}

The Japanese at Home and Abroad as Revealed

Through Their Diaries

Thirty journal excerpts written by Japanese men and women of various occupations open an

intriguing window on the Japanese psyche circa 1860-1920.

$\mathbf{5 4 4}$ pages $-\$ 25.00$, paper

\section{DAWN TO THE WEST}

Japanese Literature

in the Modern Ero

Volume I: Fiction

"An indispensable account of an entire literature."

$$
\text { - New Republic }
$$

$\$ 75.00$, cloth $\cdot \$ 32.50$, paper

THE HISTORY OF IAPANESE LITERATURE SERIES

\section{A TOWER FOR}

\section{THE SUMMER HEAT}

\section{Li Yu}

Translated, with a preface and notes, by Patrick Hanan

The most famous collection of vernacular stories from pre-modern China.

"Hanan's appreciation of the author's playfulness, social and psychological insight, and linguistic athleticism is evident."

-New York Times Book Review 256 pages - \$49.50, cloth $-\$ 15.50$, paper Translations from the Asian Classics

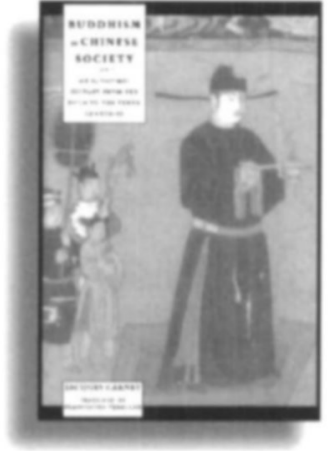

BUDDHISM IN CHINESE SOCIETY

An Economic History from the Fifth to the Tenth Centuries Jacques Gernet

"This work will remain one of this century's classic histories of China. Gernet's account of Buddhism is sobering." - Journol of Asion Studies 435 pages - $\$ 18.50$ Studies in Asian Culture

WITH A NEW PREFACE

\section{BANARAS}

City of Light

Diana L. Eck

"[Eck's] brilliant, comprehensive book seems likely to remain for a long time the definitive work on this great Indian city."

$$
\text { —Woshington Post }
$$

448 pages - 61 photos, 7 maps $~ \$ 19.50$

\section{THE HINDU} NATIONALIST MOVEMENT

\section{IN INDIA}

Christophe Jaffrelot

"A scholarly tour de force." -New York Review of Books

$\$ 36$ pages $\cdot \$ 16.50$

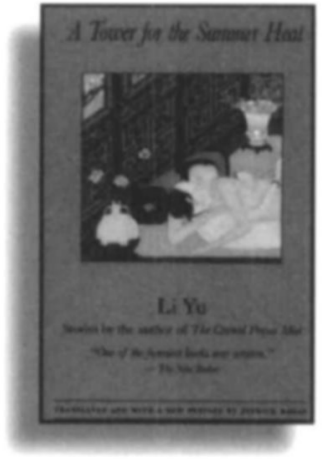

\section{ARMING JAPAN}

Defense Production, Alliance Politics, and the Postwar Search for Autonomy Michael J. Green

"With the end of the Cold War. the tension between Japan's urge for independence and its need for alliance with the United States has grown. No other author has captured this dilemma as trenchantly and readably as Michael Green." -Foreign Affoirs

206 pages - \$16.50, paper

\section{AVAILABLE FROM}

UNIVERSITY OF TOKYO PRESS

\section{A HISTORY OF}

SHOWA JAPAN, 1926-1989

Takafusa Nakamura

Translated by

Edwin Whenmouth

Available for the first time in English, this landmark history surveys Japanese life as it was lived during the Showa Era and includes a chapter on postShowa Japan on the eve of a new century.

520 pages $\cdot \$ 60.00$, cloth 


\section{SILKWORM BOOKS \\ DISTRIBUTED BY UNIVERSITY OF WASHINGTON PRESS}

The University of Washington Press proudly announces it is the North American and European distributor for Silkworm Books, Thailand.

\section{Thailand's Boom and Bust}

Pasuk Phongpaichit and Chris Baker

For ten years Thailand was the world's fastest growing economy. In 1997, it crashed.... the authors offer a lively, readable analysis of Thailand today. "This is not a simple description of trends but political economy in the broadestand most entertaining-sense."

- London Financial Times

Paper, $\$ 17.50$

\section{Guns, Girls, Gambling, Ganja}

Thailand's Illegal Economy

and Public Policy

Pasuk Phongpaichit, Sungsidh Piriyarangsan, and Nualnoi Treerat

The authors argue that control of the illegal economy in Thailand-including gambling, prostitution, drugs, arms trading, oil smuggling, and trafficking in people-is vital for the development of a modern economy.

Paper, $\$ 17.50$

\section{The Chiang Mai Chronicle}

Second Edition

Translated by David K. Wyatt and Aroonrut Wichienkeeo

This edition of one of the most important histories of northern Thailand, written in 1827, includes extensive indexes, annotations, and maps.

Paper, $\$ 24.50$

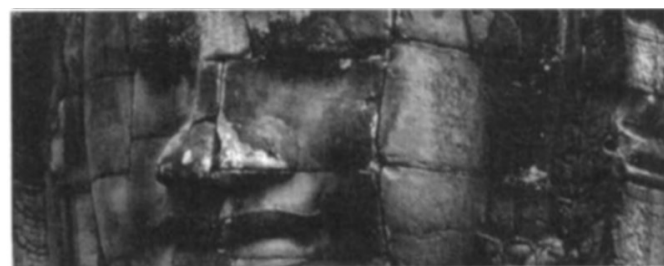

Facing the Cambodian Past Selected Essays 1971-1994

David Chandler

A leading student of Cambodia's history considers a broad range of themes and problems in this important collection of essays.

Paper, $\$ 17.50$

\section{Development or Domestication?}

Indigenous Peoples of Southeast Asia

Edited by Don McCaskill and Ken Kampe

These fascinating essays offer a range of perspectives on development among indigenous peoples of Thailand, Vietnam, Burma, Laos, and Cambodia.

Paper, $\$ 17.95$

\section{Studies in Thai History \\ Collected Articles \\ David K. Wyatt}

Preeminent Southeast Asian scholar David Wyatt brings together all his major early articles, covering topics from the early history of Siam to the origins of modern Thailand. Paper, $\$ 14.95$

For a complete list of Silkworm titles available call 1-800-441-4115

\section{UNIVERSITY OF WASHINGTON PRESS}




\section{INSTITUTE FOR}

\section{INTERNATIONAL ECONOMICS}

\section{A TRILOGY ON ASIA'S FINANCIAL CRISIS}

The Institute's world-renowned economists analyze the financial catastrophe plaguing the region and recommend urgent steps to reverse its decline.

"The Institute...is one of Washington's most influential think tanks. Its studies often frame the intellectual debate on trade and technology issues."

The Asian Financial Crisis:

- The Wall Street Journal

\section{Causes, Cures, and Systemic Implications}

Morris Goldstein

The economic turmoil that has rocked Asia is the third major currency crisis of the 1990s. How could this happen to such a high-performing region? How can the crisis be overcome and what can prevent it from happening again? Morris Goldstein explains how the Asian financial crisis arose and spread and then outlines what needs to be done to fix it. He also discusses the role of the IMF and offers specific proposals for improving the intermational financial architecture.

"A first-rate piece of work... an excellent and comprehensive discussion of why the Asian crisis occurred and what would be the appropriate policy responses. "

-Frederic S. Mishkin, Professor of Economics, Graduate School of Business, Columbia University.

June 1998. 100 pages. ISBN: 0-88132-261-X. \$11.95.

\section{Global Economic Effects of the Asian Currency Devaluations \\ Marcus Noland, Li-Gang Liu, Sherman Robinson, and Zhi Wang}

This quantitative analysis analyzes exchange rate changes caused by the Asian financial crisis and their impact on international trade and economic activity in the United States, Asia, and the rest of the world. The study examines the risk of increased protectionist pressure in the United States and what will happen if China devalues its currency.

"This is a clear and well argued analysis of the crisis in Asia...(It) adds significantly to our understanding of the key policy issues facing Asia and the United States in the aftermath of the crisis."

-Warwick J. McKibbin, Australian National University and The Brookings Institution.

July 1998. 124 pages. ISBN: 0-88132-260-1. \$15.95.

\section{Restoring Japan's Economic Growth}

Adam S. Posen

Will the Japanese government take the decisive but feasible policy actions needed to bring about economic recovery? Only one-third of the announced stimulus packages of 1992-97 was actually undertaken, and Japan's problems are due primarily to huge policy errors rather than structural problems. This timely and detailed analysis explains why a shift in Japanese fiscal and monetary policies is urgently needed and outlines a program for putting the country back on the path to solid economic growth. The author also draws broader lessons from recent Japanese policy actions that led to the economy's stunning decline.

"Japan's persistent stagnation is among the most important problems confronting the world economy today, and Adam Posen's treatment of it is the best I have seen. His analysis is right on the mark. and his policy proposals bear attention at the highest level of the Japanese government. "

-Benjamin Friedman, Harvard University

September 1998. 180 pages. ISBN: 0-88132-262-8. \$18.95.

11 Dupont Circle, NW * Washington, DC 20036-1207*

Tel: (202) 328-9000* Fax (202) 328-5432*www.iie.com 


\section{THE ASSOCIATION FOR ASIAN STUDIES WELCOMES NEW MEMBERS}

As a member, you will enjoy the fellowship and intellectual stimulation of your peers, as well as the following:

- Five issues annually of the Asian Studies Newsletter

- Four issues annually of the Journal of Asian Studies

- Three issues annually of Education About Asia (a resource for teachers and professors)

- Discounts on all other Association publications

- Reduced registration rate at our four-day Annual Meeting

Simply return the form below with your check (written in U.S. dollars on a U.S. bank) or Visa/Mastercard number to: AAS, 1021 East Huron, Ann Arbor, MI 48104.

For further information on the Association, its activities, its publications, and the advantages of membership, please contact our Membership Director; Tel: 734-665-2490; Fax: 734-6653801; E-Mail: dashton @ aasianst.org

\section{IDENTIFICATION}

Name:

Address:

Telephone(s):

Fax:

E-Mail:

Institutional Affiliation:

\section{SELECT YOUR MEMBERSHIP CATEGORY} REGULAR MEMBER

- $\$ 20,000$ or under/yr. income $\$ 25$

- $\$ 21,000-\$ 30,000 / y r$ income $\$ 45$ 口

- $\$ 31,000-\$ 45,000 / y r$. income $\$ 60$ a

- $\$ 46,000-\$ 60,000 / y r$. income $\$ 70$ 口

- $\$ 61,000-\$ 75,000 / y r$. income $\$ 80$ 口

- $\$ 76,000-$ over/yr. income $\$ 90$ 口

- patron

(one-time payment) $\$ 1,000$ or more $\square$

- Associate member $\$ 15$

(spouse of regular member/give spouse's name here:
OPTIONAL POSTAGE NEWSLETTER: OPTIONAL 1st CLASS/AIR

- USA, Canada, Mexico $\$ 8$

- C. America, S. America, Caribbean Islands, $\quad \$ 14$

- Europe $\$ 17$

- Africa, Asia, Australia $\$ 21$

ANN. MEETING PROGRAM: 1st CLASS/AIR

- USA $\$ 3$

- Non-USA $\$ 8$

- Contribution to Endowment \$

TOTAL AMOUNT:

๑ Payment enclosed

- Charge my Mastercard/Visa number:

Exp. Date

OPTIONAL BIO-DATA

口 Male $\square$ Female

Discipline: Primary: Secondary:

Primary Area of Interest:

China/lnner Asia a Northeast Asia

․ South Asia a Southeast Asia

Country of Primary Interest: 


\section{New from Duke}

\section{Flexible Citizenship}

The Cultural Logics of Transnationality AIHWA ONG

"Finally, a unique and insightful examination of transnationalism as practice. There's no better analysis of Chinese trading and commercial communities athwart the world market and multiple sovereignties."-James C. Scott, Yale University

"Flexible Citizenship exemplifies the anthropological imagination at its best In it Ong offers an analysis of states and citizenship regimes in Asia that is remarkable in its theoretical and empirical breadth. Social scientists and Asia specialists alike will find the work indispensable...."-Ashraf Ghani, Johns Hopkins University

272 pages, paper $\$ 17.95$

\section{A New Criminal Type in Jakarta \\ Counter-Revolution Today \\ JAMES T. SIEGEL}

"Siegel's amazing book thankfully appears when we need most of all to understand the mind of a dictator, the ruin he has brought upon his country's democracy, and the further horrors of which he is capable, which may consume us all."-Richard Klein, Cornell University

"Slegel tells the story of a nation not able to contain its revolution and makes us feel the pathos of its aftermath. This special book challenges any market-optimistic approach to the understanding of Indonesia and non-Western societies in general." -Rudolf Mrázek, University of Michigan

160 pages, paper $\$ 17.95$

\section{Political Change and Underdevelopment}

A Critical Introduction to Third World Politics

Second Edition

VICKY RANDALL AND ROBIN THEOBALD

"An admirable job of presenting and assessing the evolution of thinking about politics in the Third World."- Joan M. Nelson, American Political Science Review, from a review of the first edition

336 pages, paper $\$ 18.95$

\section{Duke University Press}

Box 90660

Durham, NC 27708-0660

919-688-5134

www.duke.edu/web/dupress/ 


\section{QUESTION:}

How has Japanese diplomacy failed in its handling of the Pacific War and related postwar issues?

\section{Find the ansiners in...}



Assessing the Diplomacy of Japan's Foreign Ministry from Pearl Harbor to Potsdam

By Seishiro Sugihara - Translated by Norman $\mathrm{Hu}$

"Sugihara brings further historical clarity to the war between Japan and the United States...

Sugihara has built a solid foundation upon which future scholars may build, and for the penetrating insights to be found in this book we should be truly grateful." - Masayasu Hosaka, Author and critic

“...presents a uniquely Japanese perspective on [the] attack on Pearl Harbor...analyzes a critically important, but too frequently neglected aspect of the Pacific War...should be read by serious students of Japan's wartime and postwar diplomacy." - Theodore McNelly, University of Maryland
"This is a very important book in the field of World Military History." - Hideo Miki, Japan National Defense Academy

"A nuanced perspective on many aspects of Japan's war responsibility with a distinctive emphasis on the Ministry of Foreign Affairs' role, and it interplay with Roosevelt's. Extensively documented from Japanese sources...accessible and authentic." -Edward G. Griffin, The George Washington University

1997256 pages ISBN 0-7618-0778-0 \$39.50 cloth 


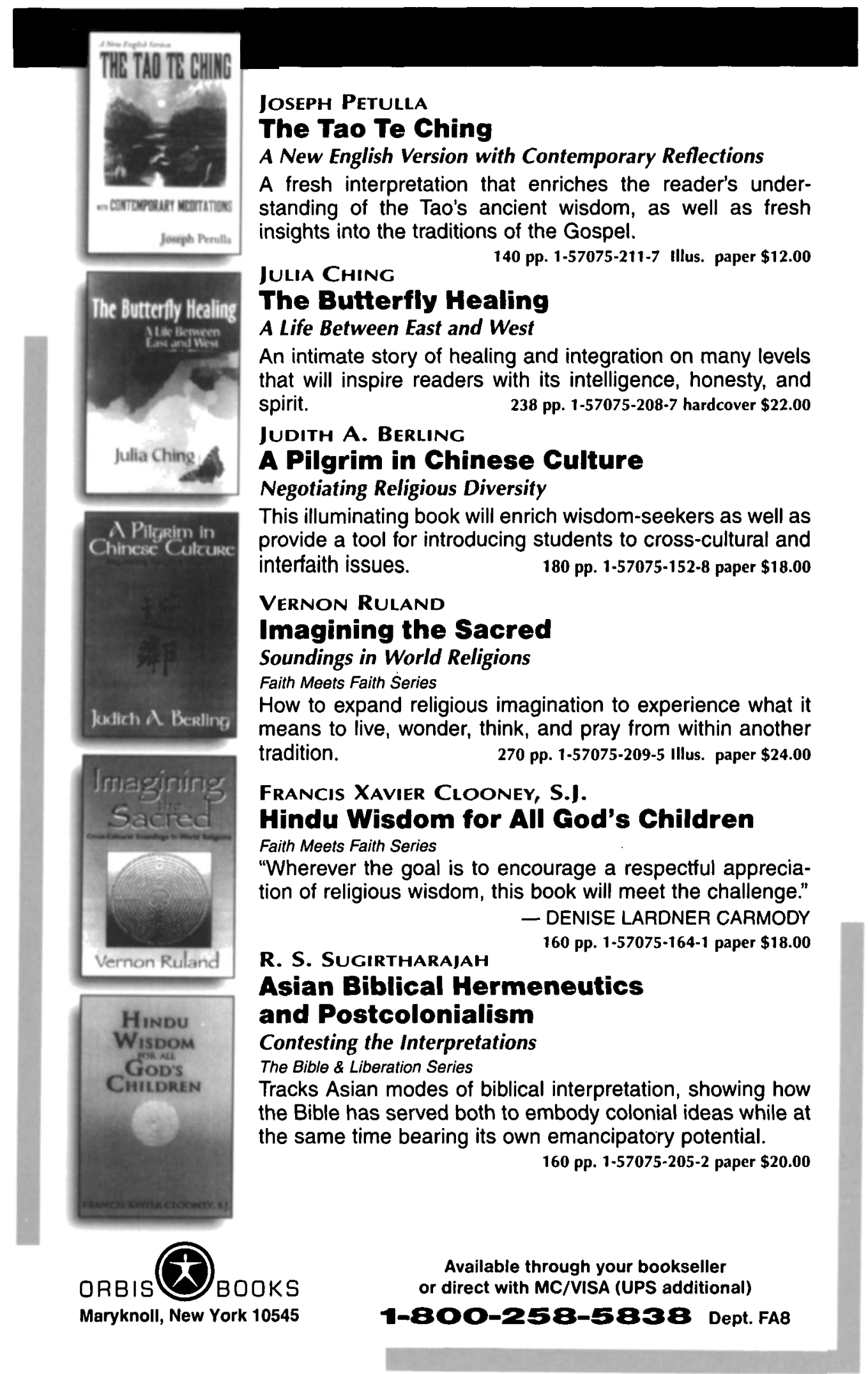




\section{POLITICS AND TRANSCENDENT WISDOM}

The Scripture for Humane Kings in the Creation of Chinese Buddhism

CHARLES D. ORZECH

"Orzech's project forces a rethinking of the relationship between religion and politics that scholars in all fields of religion will find intriguing. His focus is a Buddhist text authored in China but made to look like a translation from Sanskrit. His study excavates what the winds of history and the biases of history-writers have covered up: the fact that Tantric Buddhism occupied a crucial position in medieval Chinese civilization."

-Stephen F. Teiser, Princeton University

This volume presents for the first time a full, annotated translation of the Scripture for Humane Kings.

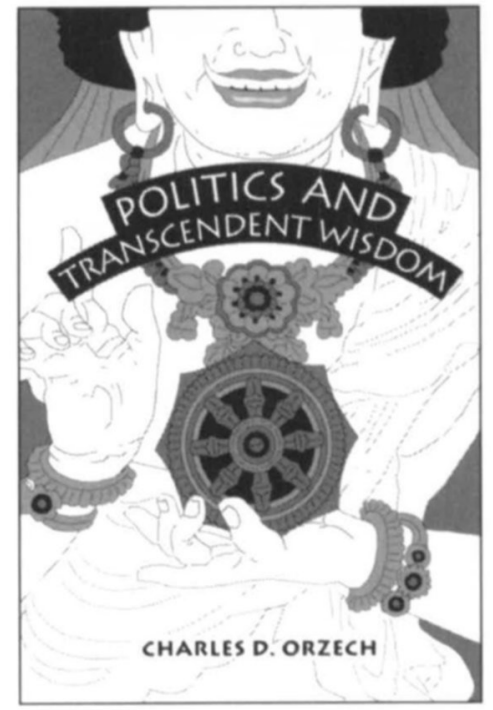

424 boaes 12 illustrotions $\$ 55.00$

\section{PENN STATE UNIVERSITY PRESS}

University Support Bldg. 1, Suite C • University Park, PA 16802-1003

Orders: 1-800-326-9180 - Toll free fax: 1-877-PSU-BOOK • http://www.psu.edu/psupress



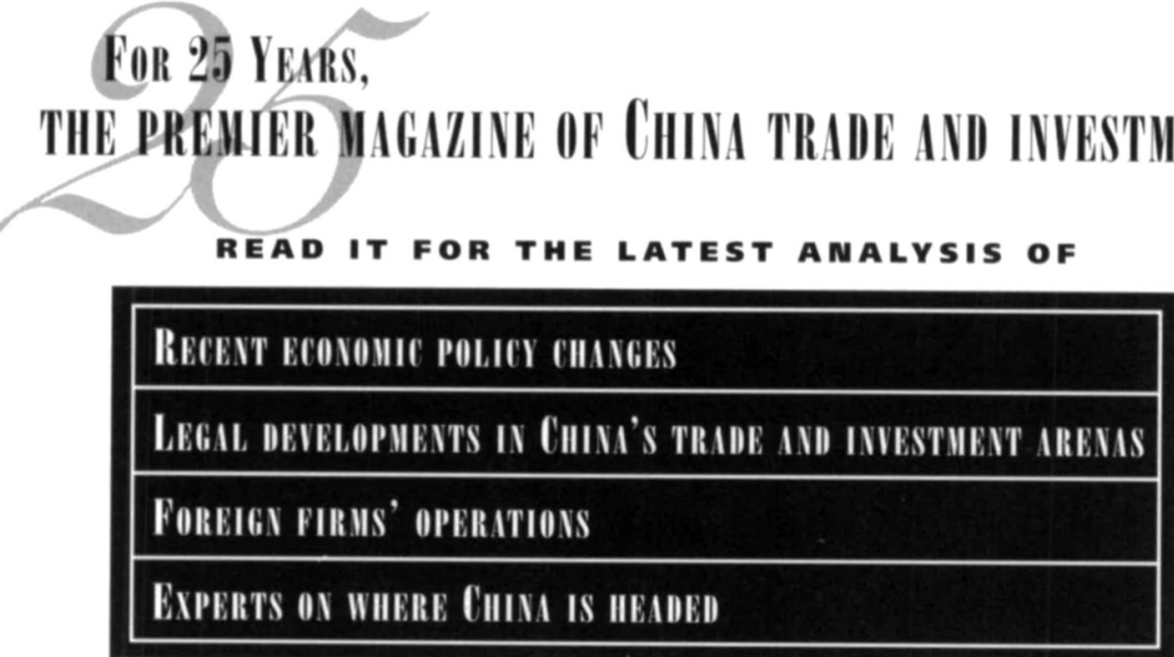

Subscribe today online at www.uschina.org/cbr

or contact Gregory Heslin, Business Manager, at Tel: 202/429-0340 Fax: 202/833-9027 
Both journals are peer-reviewed Journal of East Asian Archaeology

Editorial committee Lothar von Falkenhausen (UCLA, USA) Gina L. Barnes, Nicola Di Cosmo, Robert E. Murowchick, Sarah M. Nelson, Michèle Pirazzoli-t'Serstevens et al.

The new fournal of East Asian Archaeology includes reports on archaeological finds, contributions to archaeological synthesis, the history of archaeological research in East Asia, epigraphic and historical studies, and scholarship regarding the scientific analysis of archaeologically-excavated objects.

Also comparative issues will be discussed.

- First issue: 1999 (Two issues a year, approx. 450 pages)

- ISSN 1387-6813

- Institutions NLG 209.- / US\$119.-

- Individuals NLG 137.- / US\$ 78.-

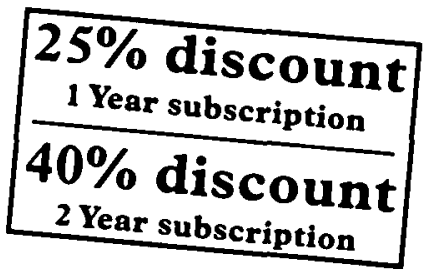

\section{NAN NÜ}

\section{Men, Women, and Gender in Early and Imperial China}

\section{Managing Editor Harriet Zurndorfer (Leiden University)}

Editorial Board Glen Dudbridge (Oxford University), Beata Grant (Washington University), Clara Wing-chung Ho (Hong Kong Baptist University), Angela Leung (ISSP Sun Yat-sen Institute, Academia Sinica), Susan Mann (University of California, Davis), Paul Ropp (Clark University)

In recent years Chinese women and gender studies have attracted more and more attention. This is reflected in an increasing number of scholarly articles from a wide variety of disciplines, now scattered among many journals, reference works, handbooks and monographs. To provide the scholarly community with a forum where the subject can be dealt with in its own right, Brill is proud to announce its new journal NAN NÜ, devoted to the study of Men, Women, and Gender in Early and Imperial China.

- First issue: 1999 (Two issues a year, approx. 300 pages)

- ISSN 1387-6805

- Institutions NLG 149.- / US\$ 85.-

- Individuals NLG 135.- / US\$ 77.-

For more information please contact our

Customer Services Department, +31 (0)71 5353566 (Please mention order code: JAS)

Brill Academic Publishers

P.O. Box 9000

2300 PA Leiden

The Netherlands

Fax +31 (0)71 5317532

Brill Academic Publishers Inc.

112 Water Street, Suite 400

Boston, MA 02109



USA

Call now 1-800-962 4406 (toll free)

Academic Publishers 


\title{
The Association for Asian Studies, Inc.
}

\author{
1021 East Huron, Ann Arbor, MI 48104 USA
}

Officers of the Association. President-WENDY Doniger, University of Chicago. Vice President-Susan L. Mann, University of California, Davis. Secretary-Treasurer-John C. Campbell, University of Michigan. Past President-James C. Scot, Yale University. PastPast President-CAROL Gluck, Columbia University.

Board of Directors. President, Vice President, Secretary-Treasurer, Past President, and Past-Past President, as listed above. Editor of the Journal of Asian Studies-ANAND A. YANG, University of Utah. China and Inner Asia Council-JoshuA A. Fogel, University of California, Santa Barbara. Northeast Asia Council-STEPHEN VLASTOS, University of lowa. South Asia Council-Gary M. TARTAKov, lowa State University. Southeast Asia CouncilLAURIE J. SeARS, University of Washington. Council of Conferences-Ronald G. KnaPP, State University of New York, New Paltz. Program Committee-Michael Aung-Thwin, University of Hawaii, Manoa.

Staff of the Association. Associate Director-MiChael PASCHAL. Comptroller-Carol J. Kelingos. Publications Manager-Ann W. Beard. Conference Manager-Karen F. Fricke. Membership Manager-Donna AsHTON. Publications Coordinator-JonATHAN WILSON. Fulfillment Coordinator-Anne Aaizala. Registration Coordinator-Joan Dewey. Accounts Receivable-LuLA W. Kromis. Office Assistant-PAt Kessler.

Sponsoring Institutions. University of Michigan and University of Utah.

\section{EDITORIAL AND SUBSCRIPTION INFORMATION}

The Journal of Asian Studies (ISSN 0021-9118), known until September 1956 as the Far Eastern Quarterly, is published by the Association for Asian Studies (formerly the Far Eastern Association) in February, May, August, and November. The annual subscription rate for the Journal is $\$ 60$ for U.S. addresses and $\$ 70$ for non-U.S. addresses, with postage included for delivery by Periodicals Postal Class. (The subscriber has the option of paying extra for delivery by U.S. First Class or Foreign Airmail.) Single issues published after February 1974 are available from the Secretariat of the Association. Issues published prior to 1958 may be purchased from A.M.S. Reprints, 56 East 13th Street, New York, NY 10003 USA. University Microfilms International, 300 North Zeeb Road, Ann Arbor, MI 48106 USA offers all volumes on either microfilm or microfiche.

All correspondence regarding memberships, subscriptions, advertising, reprints, and similar issues should be addressed to the office of the Association for Asian Studies, 1021 East Huron Street, Ann Arbor, Michigan 48104 USA.

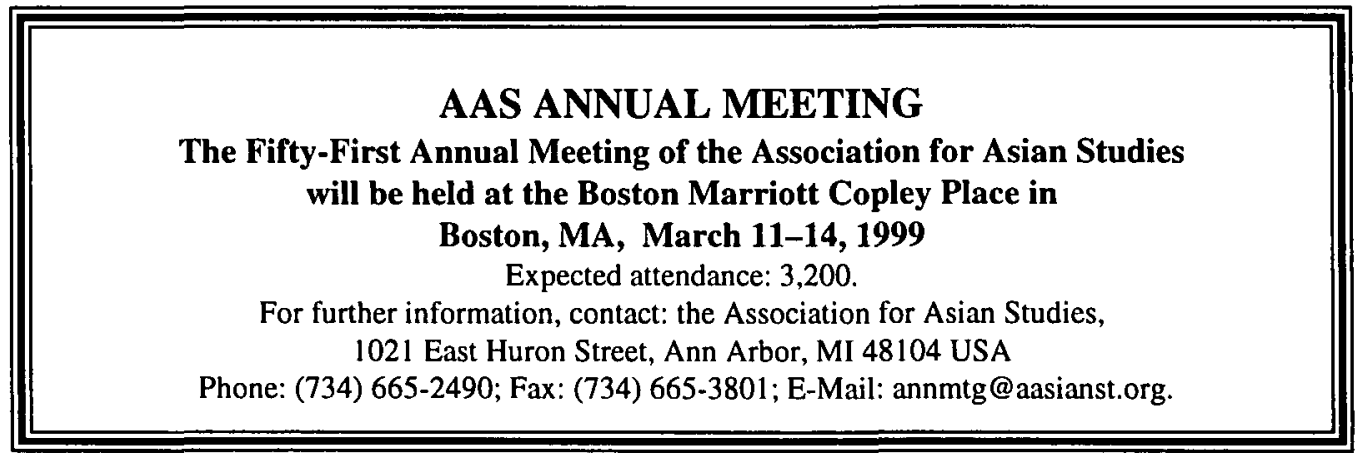


Routled

From Post-Maoism

to Post-Marxism

The Erosion of Official Ideology in

Deng's China

KAPLANA MISRA

“Kaplana Misra's excellent analysis of the complex and lingering death of theory in Chinesc Communist politics reveals how official ideology lost its privileged position in public discourse. Her meticulously rescarched study shows how ... China's reform-cra clite proved incapable of achieving meaningful intellectual consensus."

-Richard Kraus, University of Oregon

East Asia in Crisis From Being a Miracle to Needing One? EDITED BY ROSS GARNAUT AND ROSS MCLEOD

400pp $\$ 29.99 / \mathrm{pb}$

World Religions

Reader

EDITED 日Y

GWILYM BECKERLEGGE

512 pp 12 illus $\$ 24.99 / \mathrm{pb}$

\section{Gender and Power in Affluent Asia}

EDITED BY KRISHNA SEN AND MAILA STIVENS

$334 \mathrm{pp} \quad \$ 25.99 / \mathrm{pb}$

The Politics of the Environment in Southeast Asia

Resources and Resistance EDITED BY PHILIP HIRSCH AND CAROL WARREN $344 \mathrm{pp} \quad \$ 24.99 / \mathrm{pb}$

\section{Taxation in Modern} China

EDITED gy DONALD J.S. BREAN “... fills a serious gap in current research by addressing the formidable cghallenges of tax reform and fioscal overhaul in China. Eminently well-edited, carefully rescarched and thematically balanced, it is a 'must read' for scholars, policy makers and students of China's continuing market transition."

-Padma Desai, Columbia University $320 \mathrm{pp} \quad \$ 22.99 / \mathrm{pb}$

\section{Trajectories}

Inter-Asia Cultural Studies EDITED GY KUAN-HSING CHEN $416 \mathrm{pp} \quad \$ 25.99 / \mathrm{pb}$

now in paperback

\section{Hindus}

Their Religious Beliefs and Practices JULIUS J. LIPNER Library of Religious Beliefs and Practices

$396 \mathrm{pp} \quad \$ 25.99 / \mathrm{pb}$

Tourists at the Taj

TIM EDENSOR

International Library of Sociology

$240 \mathrm{pp} \quad 20 \mathrm{~b} / \mathrm{w}$ photos $\$ 25.99 / \mathrm{pb}$

\section{Embodying}

\section{Charisma}

Saints, Cults and Muslim Sbrines in South Asia

EDITED GY PNINA WERBER AND HELENE BMiSU

256pp 8 illus. $\$ 29.99 / \mathrm{pb}$

\section{Wartime Shanghai} EDITED BY WEN-HSIN YEH

\section{$232 \mathrm{pp} \quad \$ 65.00 /$ cloth}

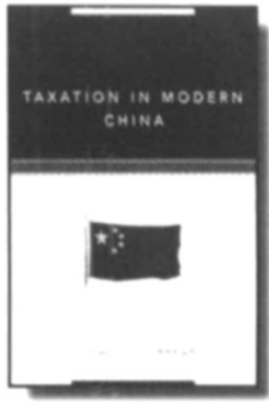

THE WORLD

RELIGIONS

READER
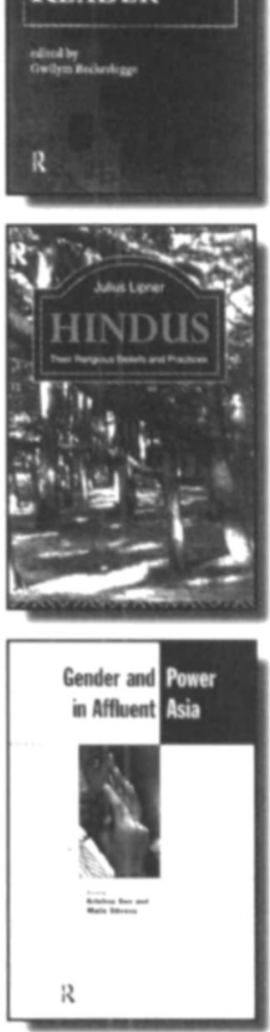

AT BOOKSTORES, or call (800) $634-7064$

fax: (800) $248-4724$

\section{ROUTLEDGE}

29 West 35th Street, N.Y., NY 10001 www.routledge-ny.com 
IN THIS ISSUE

K. W. TAYLOR

Surface Orientations in Vietnam:

Beyond Histories of Nation and Region

ERIK MUEGGLER

The Poetics of Grief and the Price

of Hemp in Southwest China

QIN SHAO

Tempest Over Teapots:

The Vilification of Teahouse

Culture in Early Republican China

HSU PI-CHING

Feng Meng-Lung's Treasury of Laughs:

Humorous Satire on Seventeenth-Century

Chinese Culture and Society

DAVID GILMARTIN

Partition, Pakistan, and South

Asian History: In Search of a Narrative 